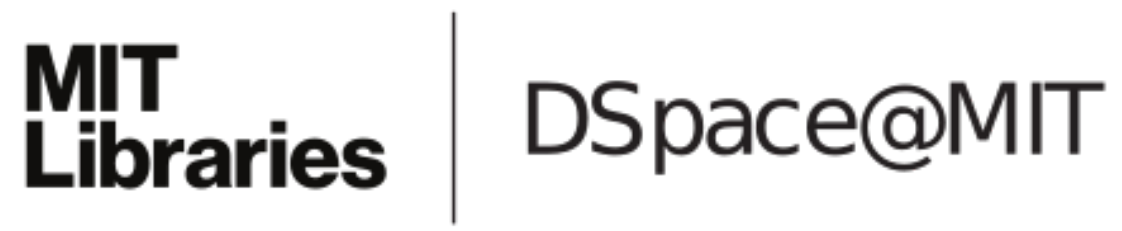

\author{
MIT Open Access Articles
}

Why regulate private firm disclosure and auditing?

The MIT Faculty has made this article openly available. Please share how this access benefits you. Your story matters.

Citation: Minnis, Michael, and Nemit Shroff. "Why Regulate Private Firm Disclosure and Auditing?" Accounting and Business Research 47, no. 5 (June 8, 2017): 473-502.

As Published: http://dx.doi.org/10.1080/00014788.2017.1303962

Publisher: Informa UK Limited

Persistent URL: http://hdl.handle.net/1721.1/121089

Version: Author's final manuscript: final author's manuscript post peer review, without publisher's formatting or copy editing

Terms of use: Creative Commons Attribution-Noncommercial-Share Alike 


\title{
Why Regulate Private Firm Disclosure and Auditing?*
}

\author{
Michael Minnis \\ University of Chicago \\ Booth School of Business \\ Nemit Shroff \\ Massachusetts Institute of Technology \\ Sloan School of Management
}

March 2017

This is an Accepted Manuscript of an article published by Taylor \& Francis in Accounting and Business Research on June 8, 2017, available online: http://dx.doi.org/10.1080/00014788.2017.1303962

\begin{abstract}
Private firms face differing financial disclosure and auditing regulations around the world. In the United States and Canada, for example, private firms are generally neither required to disclose their financial results nor have their financial statements audited. By contrast, many firms with limited liability in most other countries are required to file at least some financial information publicly and are also required to have their financial statements audited. This paper discusses and analyzes the reasons for differential financial reporting regulation of private firms. We first discuss various definitions of a private firm. Next, we examine theoretical arguments for regulating the financial reporting of these firms, particularly related to public disclosure and auditing. We then provide new survey based evidence of firms' and standard setters' views of regulation. We conclude by identifying future research opportunities.
\end{abstract}

\footnotetext{
* This paper was prepared for the ICAEW's 2016 Information for Better Markets Conference. We thank the editors, an anonymous referee, Ray Ball, Matthias Breuer, Jill Collis, Clive Lennox, Christian Leuz, and Filippo Poli (conference discussant) for detailed comments and suggestions. We also thank Andreas Barckow (DRSC), Hans Christensen, Michelle Hanlon, Andrew Sutherland, Maria D Urrea Sandoval (ICAC), and Valerie Viard (ANC) for feedback on our survey instruments. We are especially grateful to Ipek Bilgen, Michael Stern and NORC for programming the online version of our survey instrument and for administering the survey. Minnis appreciates funding support from the Accounting Research Center at the University of Chicago Booth School of Business. Shroff acknowledges financial support from the MIT Junior Faculty Research Assistance Program.
} 


\section{Introduction}

The location of a private firm substantially affects its financial reporting environment. Private firms in the United States and Canada, for example, essentially face no financial reporting regulation. They are required to neither make their financial reports public nor have them audited. As a result, the extent to which these firms engage in public reporting or financial auditing is effectively a result of the firm weighing its private costs and benefits. They consider an auditor's fees, the amount of time required to undergo an audit, the proprietary costs of making their results public, etc., and trade these costs off with potential capital market benefits such as lower borrowing costs or more freely available trade credit. By contrast, firms in many other countries throughout the world face a substantially different financial reporting regulatory environment. A limited liability private company in the U.K., for example, is required to have its financial statements audited and made publicly available, regardless of the firm's own considerations of the private costs and benefits. ${ }^{1}$

These differences in disclosure and auditing regulations result in tremendous differences in reporting outcomes. In the U.S., for example, only rarely will a private company voluntarily disclose any financial reports, regardless of firm size. Some of the largest firms in the U.S. are private and do not disclose their financial results. Moreover, the majority of even medium-tolarge private firms in the U.S. do not produce audited GAAP statements (Lisowsky and Minnis 2016). ${ }^{2}$ In Europe, on the other hand, most firms of material size (e.g., assets of EUR 5 million and 50 employees), have to disclose financial statements publicly and have them audited. Firms smaller than various thresholds face lower financial reporting requirements, but even then some aspect of disclosure is typically required (e.g., Burgstahler et al. 2006; Bernard et al. 2015).

In this paper, we consider various arguments for and against regulating the disclosure and

\footnotetext{
${ }^{1}$ These requirements are conditional on a firm's size, which we discuss in Section 2. See also Collis (2012).

2 The majority of small firms in the U.S. do not even produce financial statements (Allee and Yohn 2009).
} 
auditing of private firm financial reports. We do so in three progressive steps. In Section 2, we consider what defines a private firm. Individuals could have different views on essential aspects of what makes a firm "private," and this could lead to differing views on regulation of those firms. For instance, one could view a firm that controls large amounts of societal resources (e.g., physical or human capital) as a "public" firm and one that does not as a "private" firm. In other words, a private firm would be defined by its systemic importance or footprint on the economy. Another is a legal perspective where firms with limited liability are considered public while firms with unlimited liability are private. A third perspective, and the one we adopt in this paper, is a capital perspective: a private firm is one which does not have capital—equity or debttraded on a secondary market. We discuss our motivation for this perspective and how it shapes one's view on theoretical arguments relating to regulation in Section 2.

In Section 3, we review the arguments for and against financial reporting regulation from the academic literature (see also Leuz 2010, Leuz and Wysocki 2016). These arguments consider both the benefits—such as externalities, processing costs, and reduction of duplicative effortsand the costs—-such as regulatory capture, implementation costs, and loss of revealed preference information. We note that the extent to which each of the benefits and costs weighs into a country's culture and institutional framework is likely to shape the country's level of regulation (Leuz 2010).

To better understand how these costs and benefits are perceived by both the regulators and the regulated, we examine new survey evidence in Section 4. We surveyed 25 accounting standard setters around the world and more than 2,000 companies throughout Europe to gain a sense of how theoretical and empirical findings from academic literature hold up to respondents' perceptions. Perhaps not surprisingly, we find standard setters view the benefits of public disclosure and auditing requirements as exceeding the costs more often than firms do. One of the firms' most important concerns about public disclosure is their competitors' ability to observe 
not only their financial performance (e.g., Botosan and Stanford 2005; Berger and Hann 2007; Dedman and Lennox 2009), but also the extent of their financial constraints (e.g., Bernard 2016). In further support of this evidence, firms report they often seek out their competitors' financial information. However, in finding that firms use the information reported in their competitors' financial statements, these findings also provide evidence of a necessary condition for the existence of positive externalities of public disclosure. Firms can use the mandated public reports to potentially make better investment decisions and lower their cost of capital (e.g., Badertscher, Shroff and White 2013; Shroff, Verdi and Yost 2017). Thus, we provide first hand evidence of firms revealing themselves as observing their competitors' financial reports.

Firms also overwhelmingly indicate they would not voluntarily file financial statements publicly if the mandate were removed. Thus, firms state that private costs of public disclosure outweigh the private benefits. Interestingly, however, the majority of firms also state they support a rule requiring public reporting. So while they do not view public financial disclosure as an optimal strategy unilaterally, they seem to prefer a system which requires all firms to disclose, an approach different from regimes such as those in the U.S. and Canada. ${ }^{3}$

We also inquire about firms' views of the financial statement audit requirement. In contrast to the public disclosure requirement, firms suggest that private markets for auditing are sufficient. Relative to the public disclosure requirement, more firms view an audit's benefits exceeding the costs; however, the majority of firms would prefer that mandates for auditing be removed. The view seems to be that, while firms reap private benefits from having an audit (e.g., lower interest rates on debt), little positive externality benefits for an audit exist. As such, firms view mandates as unnecessary.

Collectively, we review the literature and offer new survey-based evidence on firms' and

\footnotetext{
${ }^{3}$ A potential explanation for firms stating they would not disclose if not required, but at the same time supporting a rule that all firms disclose could be that some firms are harmed less by disclosure than their competitors. Thus, a rule mandating disclosure is optimal for some firms. See Mian and Smith (1990) for an example.
} 
standard setters' views on disclosure and reporting requirements for private firms. The evidence is mostly consistent with theory and prior research: the private costs of disclosure and auditing exceed the private benefits for private companies; but there is potential for externality benefitsespecially of disclosure. That is, benefits of public disclosure by private companies very likely exist if there is collective disclosure. Nevertheless, regulators are subject to agency concerns themselves (e.g., Stigler 1971; Peltzman 1976) and a regulatory approach to increase social welfare still may not lead to the most efficient outcome despite its benefits. Ultimately, the extent of societal benefits of financial disclosure and auditing remains open. To make further progress, one needs to consider a social welfare criterion—what does society value —and how cultural and institutional factors lead to differences in welfare criterions. Moreover, in this paper we focus on regulating the disclosure and auditing of financial reports, and do not discuss regulating the set of accounting and reporting standards. ${ }^{4}$ These are issues beyond the scope of this paper, but given the importance of the private firm setting and the rich heterogeneity across countries in terms of both reporting differences and institutional differences, this creates an interesting setting for future research, which we discuss in Section 5.

\section{What are private firms and how is their disclosure and auditing regulated?}

\subsection{What are "private" firms?}

Before discussing theoretical motivations for and against regulating the financial reporting of private firms, it is worth briefly discussing what we mean by a "private firm." Indeed the very definition of a private firm may lead to different interpretations or views on how those firms should be regulated. For instance, one viewpoint is that a private firm is one with a small societal or economic impact and, by contrast, public firms are those with a large impact. Of

\footnotetext{
${ }^{4}$ Our discussion of auditing regulation is limited to whether firms should (or should not) be required to get an audit. We do not consider other dimensions of auditing regulation such as the optimal auditing standards and whether auditors should be regulated by a public regulator such as the Public Company Accounting Oversight Board in the U.S. (see Aobdia and Shroff 2017 for a discussion of such issues).
} 
course, measuring the "societal impact" of a firm would be the next (difficult) task. Should "societal impact" be measured based on the number of employees of the company, the number of investors in the company, or total physical capital controlled? If so, then the next logical question is at what point does a firm have a large societal or economic impact?

In this paper, we do not include any notion of "societal impact" in our definition of a private firm. Instead, for the purpose of this paper, we view a private firm as one with capital (e.g., debt or equity) that is not traded in a secondary market. The defining feature of a public firm, therefore, is that its capital can be transferred between two investors in a market with littleto-no involvement of the firm itself and in which the two investors are not required to be familiar with one another. Under this definition, small firms with little impact on society or the economy could be "public" and very large international firms could be "private." Of course, this definition does not perfectly segregate all firms as being private or public. For example, one could debate what is meant by capital or whether one should only consider equity and not debt capital to classify firms as private or public. Katz (2009), for instance, considers firms with private equity, but publicly traded debt, as private firms. Under our definition, such firms are public firms. ${ }^{5}$ One could further debate what is meant by a "market.” Certainly, a market would include public stock exchanges, but we intend to include over-the-counter exchanges as well. Moreover, our definition notes the distinction between a "private" firm and a "dark" firm: the former does not have shares traded on an exchange, while the latter does (and therefore is still a public firm) but is not required to file reports with a regulator (Leuz, Triantis, and Wang 2008). Ultimately, no definition is perfect, but to focus the paper on interesting economic issues and avoid a definition which, by construction, leads one to conclude that all public firms should be regulated and all

\footnotetext{
${ }^{5}$ However, it should also be noted that Katz (2009) uses the qualifying term "privately held" indicating that the firm is private specifically from an equity perspective. Other papers do not always make this important qualification, however, when it is appropriate.
} 
private firms should not, we take a private capital (i.e., equity or debt) based perspective as that which defines a private firm. ${ }^{6}$

One important aspect to note is that throughout this paper we limit our discussion to private companies with limited liability. This is important because in many countries firms with unlimited liability (e.g., sole proprietors) face significantly less financial reporting regulation. We focus our discussion on limited liability firms because unlimited liability firms are typically very small and have limited financial sophistication or scope. See Ball and Shivakumar (2005), Burgstahler et al. (2006), Lennox and Li (2012), and Bernard et al. (2015) for discussions of various regulations. We discuss our reasoning further below.

\subsection{How are private firms' disclosure and auditing regulated across countries?}

Private firms face substantially different financial reporting regulations, such as the requirement to publicly disclose financial statements and obtain an audit, depending on their country. While the purpose of our paper is not to delineate all possible regulations that various firms face, we discuss a variety of regulations because the heterogeneity reveals the extent to which different approaches to regulate private firms have been taken. ${ }^{7}$ At the risk of severe oversimplification, we classify countries into one of two regimes: limited regulation and legal

\footnotetext{
${ }^{6}$ To reinforce the notion that defining a private firm is not straightforward, the U.S. accounting standards did not consistently delineate a "public" firm from a "nonpublic" firm until 2013 with the Accounting Standards Update No. 2013-12 (FASB 2013). Interestingly, the FASB decided to define what a public firm is instead of defining a private firm (the original discussion memorandum discussed defining a private firm). According to FASB, a public firm—or more precisely, a "Public Business Entity"-is one that is neither "a not-for-profit entity nor an employee benefit plan" and, essentially is required to file (or voluntarily files) financial statements with the Securities and Exchange Commission (SEC) or other "regulatory agency in preparation for the sale of or for the purposes of issuing securities" (FASB 2013, p. 5). In other words, in the U.S., the FASB broadly defines public business entities as those that are required to file financial statements publicly as defined by a regulator such as the SEC.

${ }^{7}$ The discussion in this paper is limited to regulation of financial statement disclosure and auditing for parsimony. An important part of financial reporting regulation that is not discussed in this paper relates to accounting standards or GAAP. The theoretical arguments for the approaches to accounting standard setting are significantly different than those for public disclosure/auditing, and as such, are beyond the scope of this paper. We refer the interested reader to Healy and Wahlen (1999) and Kothari, Ramanna, and Skinner (2010) for reviews of the literature. For an example of a discussion of the role of accounting standards within a specific context (e.g., Germany), see Leuz and Wustemann (2004).
} 
form based regulation. We discuss both regimes in this section.

\subsubsection{Limited regulation regimes}

The "limited regulation" regime is one in which private companies face little regulation from a financial reporting perspective. The two countries that best fit within this regime are the United States and Canada. With limited exceptions, private companies in these countries are required neither to have their financial statements audited by a public accountant nor to file their financial statements publicly—regardless of the size or legal form of the company. ${ }^{8}$ Companies that are typically required to publicly disclose their financial statements in these countries are only the firms with a dispersed ownership in some class of security. In the U.S., for example, there are two criteria that determine the public disclosure requirements for companies: (1) the company has at least \$10 million in assets; and (2) the company has more than 2,000 individuals owning its securities (debt or equity). ${ }^{9}$

A salient feature of this definition is the SEC regulates firms based on the "securities" issued and does not necessarily focus on equity. Under this definition, firms with closely held equity but publicly traded debt are public firms, not private firms. Second, the size requirement (i.e., \$10 million in assets) is typically not a binding constraint. Lisowsky and Minnis (2016) use a confidential dataset with the returns of all companies filed with the U.S. tax authority (IRS) during the years 2008 to 2010. They find approximately 70,000 firms in the U.S. in any given year with at least $\$ 10$ million in assets, but no SEC filing requirement because the number of

\footnotetext{
${ }^{8}$ An important exception in the U.S. is financial firms (e.g., Beatty, Ke, and Petroni 2002). All banks, for example, are required to report their financial statements to banking regulators which are then made publicly available. In rare circumstances, individual states within the U.S. legislate financial reporting for certain firms. One example is grain dealers in the state of Iowa, which are required to submit "a financial statement that is accompanied by an unqualified opinion based upon an audit performed by a certified public accountant licensed in this state.” However, the financial statements are not made publicly available. See Section 203 at https://www.legis.iowa.gov/.

${ }^{9}$ The rule also applies if the firm has 500 non-accredited investors. See Title V of the JOBS Act for more details: https://www.gpo.gov/fdsys/pkg/BILLS-112hr3606enr/pdf/BILLS-112hr3606enr.pdf.
} 
owners of record is less than the regulatory standard. ${ }^{10}$ Thus, the public filing requirement is based primarily on the ownership distribution of its securities (and only nominally on the size of the firm). As a case in point, multi-billion dollar companies such as Cargill, Inc., Koch Industries, Inc., and Uber do not have any public disclosure requirement in the U.S. Canada, and to a lesser extent China, have a similar set of rules. ${ }^{11}$ In sum, the U.S. and Canada have regulatory regimes such that private firms are largely free of any financial reporting and auditing requirements. ${ }^{12}$ That is, private firms are essentially able to remain private (and choose the type of financial reporting they follow-or even whether to produce financial reports at all), while public firms not only publicly disclose their financial results but also have their financial statements verified by an independent auditor.

\subsubsection{Legal form based regimes}

In contrast to the above settings, companies in countries with "legal form" based regulatory regimes face regulations not explicitly linked to the dispersion of security holdings, but instead based on the legal form and size of the firm. As such, many private firms (based on our definition) face financial reporting regulations because they have limited liability, regardless of whether they have few owners (or even only one) and no debt. Specifically, limited liability companies above certain size thresholds in these countries are required to disclose their financial statements publicly and have their financial statements audited. To the best of our knowledge, a

\footnotetext{
${ }^{10}$ Therefore, while "size" is technically part of the public disclosure regulation, we do not consider the U.S. to be a size-based regulatory regime because size is not a binding constraint. As an interesting example of this, Facebook reportedly had an initial public offering not because it wanted access to public securities markets, but because its employees were selling shares of stock, which effectively pushed the company above the 500 shareholder (preJOBS Act) threshold (Solomon 2011).

${ }^{11}$ According to the Canadian governmental organization, Innovation, Science and Economic Development Canada, "Most corporations do not need to file financial statements with Corporations Canada." The firm has to be a "distributing firm," which is a reporting issuer under the "meaning of applicable securities regulation." See http://www.ic.gc.ca for additional information.

${ }^{12}$ All limited liability firms in the U.S. and Canada must file tax returns with the national government in accordance with tax rules. However, these forms remain confidential and are not required to have an independent accountant involved.
} 
majority of countries outside of the U.S., Canada, and China fit into this category. This does not mean that all countries within this category have the same set of regulations, however. Countries such as Japan, South Korea, and Australia have different rules from one another and have different rules from countries in the European Union, for example. Moreover, even countries within Europe - the focus of our discussion—face heterogeneous regulations.

In Europe, the extent of financial disclosure and independent auditor verification for limited liability private firms is dependent on size. Firm size is categorized along three dimensions: assets, turnover (i.e., sales revenue), and the number of employees. Other studies investigate the financial reporting regulations country-by-country in detail within Europe (e.g., CNA Interpreta 2011; Bernard, Burgstahler, and Kaya 2015), so we only briefly discuss them here. We summarize the rules visually in two ways. First, in a study conducted for the European Commission, CNA Interpreta assembled an "Accounting Matrix" for each country. We have reproduced this matrix as Figure 1. This matrix highlights the set of rules (down the side of the matrix) and the definitions of firms for which those rules apply (across the columns). As the chart demonstrates, the regulations cover issues such as prescribed accounting rules the firms must follow, what types of information must be disclosed in the financial reports, and whether the financial reports must be audited. Across the top of the chart, firms are differentiated by their size. We refer the interested reader to the extensive body of the report which details how each country differs according to both the definition of company size and the set of rules within each cell conditional on company size.

Bernard et al. (2015) also document the set of reporting regulations in place for nine major European countries for the years 2003 through 2011. That study focuses on regulations relating to disclosure and auditing only and reports the size thresholds relating to the number of employees, total assets, and sales turnover, above which firms must more fully disclose income 
statement and balance sheet items or have their financial statements audited. We visually represent these rules by country in the collection of charts in Figure 2. There are several takeaways from these charts. ${ }^{13}$ First, despite the European Commission providing guidance on size thresholds, we see variation across countries, with Germany and Denmark generally setting the highest size thresholds and Ireland and France setting the lowest. ${ }^{14}$ Second, we see regulation has eased over time for almost all countries (with the exception of Ireland). These changes over time are a combination of inflation adjusted settings and changes in settings as a result of regulators explicitly changing regulation to ease the reporting burden of smaller entities (Ball and Shivakumar 2005; Kausar, Shroff and White 2016). Third, most of the variation (both across countries and time) is related to assets and sales and not the number of employees. With respect to the number of employees, France has the tightest regulations for disclosure and is the only country to slightly adjust the regulatory threshold. Finally, these charts also highlight that in addition to the significant heterogeneity within Europe, collectively these countries are much more aligned with one another than with the U.S. and Canadian "limited regulation” regimes.

Returning to the question we are discussing: why regulate private company financial reporting? It is interesting to note how two major economic regions have chosen vastly different approaches to regulate the financial reporting of private companies. The U.S. and Canada focus almost exclusively on a dispersion of security ownership, with size generally not a binding constraint. Thus, private firms face essentially no reporting regulation. European regulations, on the other hand, focus on the firm's legal liability and size (along three dimensions). As we discuss next, regulating private company financial reporting is not without costs and we are aware of no academic research that qualifies whether there is a net benefit to regulation (i.e.,

\footnotetext{
${ }^{13}$ All figures except the number of employees are reported in Euros. Where applicable, we use an average currency foreign exchange rate for the given year.

${ }^{14}$ See also Collis (2010) for a discussion of thresholds for auditing in the U.K. and Denmark.
} 
whether the benefits of regulation exceeds its costs). Thus, while we can highlight the costs and benefits of private company reporting regulation and provide some insight into which arguments are supported in the data, at this point, it is impossible to tell which approach is preferable in terms of maximizing social welfare. Moreover, because institutional features differ by country, any such analysis would need to take these features into account.

\section{Why regulate financial reporting and disclosure?}

One of the primary purposes of financial reporting is to reduce agency problems among the many stakeholders in a company. ${ }^{15}$ Agency problems exist between managers and investors, between current and potential investors, among the current investors (e.g., majority vs. minority shareholders, debt vs. equity investors), between the company and its customers and suppliers. Broadly speaking, financial reporting helps reduce agency costs by reducing information asymmetry between, and facilitating contracting among, stakeholders in companies.

Even though there is ample evidence that companies derive economic benefits from transparent financial reporting and from having their financial statements audited by way of reduced agency costs (see Dechow, Ge, and Schrand 2010 and Leuz and Wysocki 2016 for reviews of the literature), this does not imply that financial reporting should be regulated (Ross 1979; Easterbrook and Fischel 1984). Rather, it is precisely when companies obtain net benefits from disclosing information (or getting an audit) that these benefits provide firms incentives to voluntarily disclose information (and get an audit), thereby making regulation unnecessary. Prior research such as Jensen and Meckling (1976), Ross (1979), and Grossman (1981) among others suggest that at least part (if not all) of the costs of obfuscating information and non-disclosure are ultimately borne by the company (i.e., its current investors, including managers). Thus,

\footnotetext{
${ }^{15}$ An agency problem can be broadly thought of as a conflict of interest inherent in any relationship where one party is expected to act in another's best interests.
} 
companies have strong market-based incentives to disclose their financial statements to stakeholders and obtain an audit, which then reduces agency costs borne by the company.

Notably, though, there are also economic justifications for financial reporting regulation. These arguments are typically based on the premise that the market solution is unlikely to result in the socially desirable level of disclosure and transparency. Research in regulatory economics proposes a number of arguments to justify financial reporting regulation. We begin by discussing some of the salient arguments for why regulation can be beneficial in a general context before discussing the arguments that apply specifically to private companies. Of course, the benefits of regulation come with important costs as well, which we also discuss. In the discussion that ensues, we broadly refer to both disclosure and auditing as financial reporting for brevity. We make explicit distinctions where needed.

\subsection{Potential benefits of financial reporting regulation}

\subsubsection{Externalities and spillover effects of financial reporting}

One of the primary theoretical justifications for regulating financial reporting and disclosure is because of its externalities on other companies (Dye 1990; Admati and Pfleiderer 2000; Lambert, Leuz, and Verrecchia 2007). Since the companies operating in an economy are affected by common economic conditions, such as common demand, supply and cost conditions, the disclosures of one company can help inform stakeholders in other companies about these common economic factors. In addition, an individual company’s disclosures can be informative to even economically unrelated firms if these disclosures provide information about technological innovations, governance arrangements such as compensation practices, etc.

A growing body of research finds empirical support for the idea that disclosures of one firm have important economic effects on other related firms. For example, Bushee and Leuz (2005) find that a regulatory change mandating over-the-counter bulletin board (OTCBB) firms 
in the U.S. to comply with reporting requirements under the 1934 U.S. Securities Exchange Act led to positive stock price reactions and permanent increases in liquidity-even for those firms that were already compliant with these requirements. Their evidence suggests that stricter disclosure regulation generates positive externalities in the form of liquidity spillovers. Badertscher, Shroff and White (2013) find that, in the U.S., firms operating in industries with a larger proportion of public firms make better investment decisions than those operating in industries with a smaller proportion of public firms. They argue that U.S. public firms disclose large amounts of information due to mandatory disclosure requirements and voluntary disclosure incentives. By contrast, U.S. private firms are not required to disclose information publicly (and very rarely do). ${ }^{16}$ Thus, the composition of public and private firms in the U.S. has significant effect on the industry's information environment. They further show that the proportion of public firms does not affect the quality of investment decisions in the U.K., which they attribute to the fact that U.K. private firms are required to publicly disclose their financial statements. Thus, the evidence in Badertscher et al. is consistent with disclosures having positive externalities.

Shroff, Verdi, and Yu (2014) find that disclosures of peer firms help reduce agency problems in multinational firms by better informing the parent firm about the economic environment of its foreign subsidiaries. Shroff, Verdi, and Yost (2017) find that peer-firm disclosures help reduce the cost of capital for other firms in the industry and that such externalities are time-varying; firms benefit the most from their peer-firms' disclosures when they are young and have little public information about them. The benefit of peer-firm disclosures dissipates as the firm becomes older and begins to provide more disclosure directly.

\footnotetext{
${ }^{16}$ In addition to the disclosures made by private financial firms discussed in the previous section, there are exceptions to private firm disclosures in the U.S. For example, some U.S. private firms voluntarily participate in the Forbes annual ranking of the largest private companies by providing sales revenues (however, even some of the information Forbes' uses is based on estimates). Other firms voluntarily provide some level of data to information bureaus such as Dun and Bradstreet to facilitate credit analyses. However, specific firm-provided financial data (such as complete income statements and balance sheets) are provided sparsely.
} 
However, other research suggests that if disclosure is of poor quality it can generate negative externalities. For example, Durnev and Mangen (2009) find that misreporting by one firm can lead to distorted investment decisions by peer firms.

While the above studies concern the spillover effects of financial reporting on the investment behavior of peers, some recent research also examines the externalities of one firm's disclosures on the disclosure behavior of other firms. For example, Baginski and Hinson (2016) find that the decision by some firms to stop providing management forecasts motivates peer firms in the same industry to begin providing management forecasts to compensate for the loss of information (via information transfers) from the first firm's decision to cease forecasting. Breuer, Hombach and Muller (2016b) and Arif and De George (2016) provide similar evidence on the interaction of disclosure decisions of peer firms.

Collectively, prior research provides evidence of positive externalities of public disclosure in a variety of settings. This finding is important because companies are unlikely to consider the benefits their financial statements and disclosures provide to stakeholders in peer companies when choosing their optimal level of disclosure. Thus, if these externalities of disclosure are sufficiently positive, regulation that factors in these externalities have the potential to be welfare enhancing for the economy as a whole. It is important to note, however, that these papers document a potential benefit of external reporting, but are unable to conclude that these benefits of external reporting outweigh the costs. For example, while private firms may benefit from the reporting of public firms, the papers are unable to document the potential negative externality on the investment choices of public firms.

\subsubsection{Standardization and processing costs}

Financial reporting regulation can produce cost savings for the economy by standardizing information and making it easier for users to process (Mahoney 1995; Zingales 2009). Even if 
firms are entirely forthcoming in their disclosures, there are several ways to measure performance and compile financial statements. In the absence of standardization, stakeholdersespecially lenders and potential equity investors_evaluating and comparing the performance of several firms then face the added cost of making the disclosure of different firms comparable. Thus, regulation that standardizes disclosure and financial statements can benefit market participants.

Consistent with this argument, a number of recent studies find that the adoption of International Financial Reporting Standards (IFRS) across several different countries helped reduce information processing costs for foreign investors. IFRS adoption increased cross-border investment by increasing financial statement comparability and familiarity among foreign investors whose home country also adopted IFRS (see e.g., DeFond, Hu, Hung and Li 2011, Florou and Pope 2012, Yu and Wahid 2014; see De George, Li and Shivakumar 2015 for a review of the literature).

\subsubsection{Reducing duplicative effort}

Absent financial reporting regulation, managers and stakeholders will likely have to negotiate disclosure requirements. Such negotiation is costly in terms of manager and stakeholder time involved. Financial reporting regulation can produce cost savings for the economy as a whole if it helps reduce duplicative efforts to negotiate disclosure requirements with different stakeholders, especially if the results of such private negotiations are unlikely to vary much (Mahoney 1995). Say, for example, all stakeholders in a company demand some basic information such as the company's balance sheet and income statement. In such a scenario, regulation that requires companies to provide a minimum level of disclosure that includes the balance sheet and income statement can result in economy-wide cost savings by providing a standardized solution. 


\subsubsection{Enforcement}

Finally, while market based solutions and private contracting arrangements have the ability to punish non-compliance (e.g., class action lawsuits), they typically have fewer options in terms of punitive powers. Violation of a private contracting arrangement, in general, can only result in monetary penalties and sanctions. However, public regulators often have the power to impose criminal penalties if their rules are violated (Jackson and Roe 2009). The ability to impose criminal penalties can be especially important in circumstances where the entrepreneur seeking capital has a small net worth that constrains the maximum monetary penalty possible. If the penalty necessary to incentivize the desired behavior exceeds the wealth of the contracting parties then a regulatory solution could help by also imposing non-monetary, perhaps criminal, penalties (Shavell 1986)-i.e., double jeopardy.

Related to the above, private parties will litigate cases of fraud and deceptive financial reporting practices only when the expected benefits of such litigation exceed expected costs. That is, stakeholders are willing to invest in enforcement and litigation against wrongdoers only if they at least break even from this action. However, a regulator could enforce cases even when the fines/sanctions imposed for wrong-doing is less than enforcement costs. This benefit is particularly important when the damage from the financial reporting violation is large since it is then optimal to deter other potential violators (Polinsky 1980).

\subsection{Costs of financial reporting regulation}

It is important to recognize regulation imposes significant costs that need to be balanced against the benefits of regulation. Coase's (1960) primary criticism of traditional theories of regulation is that they compare market failures to an idealized form of regulatory intervention, where the regulator is not affected by agency problems and information asymmetries. Some of the salient costs of regulation are as follows. 


\subsubsection{Special interests versus public interests}

Regulatory processes are far from perfect because regulators also have agency problems (e.g., Stigler 1971; Peltzman 1976). That is, regulation is typically created by political processes, which have shortcomings. Prior research finds that incumbents oppose regulatory regimes that undermine their competitive position and advocate for regulation that protects their position. For example, Rajan and Zingales (2003) and Granja (2016) find that incumbent firms oppose disclosure regimes that make it easier for new entrants to raise capital as it fosters competition. A regulatory solution needs to be designed such that it serves the public interest rather than special interests. However, since special interests have greater incentives to shape the manner in which they are regulated (e.g., through lobbying efforts and political contributions), regulatory solutions in practice are often influenced by the special rather than the public interest.

\subsubsection{Information asymmetry between regulators and companies}

Individual companies are much better informed than regulators about the costs and benefits of financial reporting and disclosure to them. For example, firms are better informed about the proprietary costs of disclosing information. If mandatory disclosure forces firms to reveal significant proprietary information, firms might choose to invest less in projects that generate proprietary information (e.g., R\&D). Thus, mandatory disclosure requirements can discourage investments ex ante, negatively affecting social welfare.

Consider a recent example. Bernard (2016) hypothesizes that information about a firm's financing constraints is proprietary in nature because this information can be used by competitors to prey on weaker firms. If information about a rival's financings constraints is public, cash rich firms can force economically efficient but financially constrained rivals out of business by lowering industry profits and reducing their rivals' cash flows. Bernard provides empirical support consistent his hypothesis. However, an important limitation of his empirical analyses 
(which he recognizes) is the difficulty in separately identifying the difference between competition and predation: does disclosure lead economically efficient (but financially constrained) firms to exit the market or does it just lead economically inefficient firms to exit the market (Shroff 2016)?

Taking the evidence in Bernard (2016) as given, Shroff (2016) discusses that financially constrained firms then have to make a difficult choice: (i) either take on leverage, which can facilitate faster growth but at the same time expose the firm to a higher risk of predation by cashrich rivals, or (ii) just keep leverage ratios and financing constraints low even if that means settling for a slower growth rate. Insofar as regulators are less informed than firms about the costs of financial reporting and disclosure to firms, it is plausible that financial reporting regulation can be welfare decreasing as the above example suggests. Much additional research is needed to distinguish between the economic effects of competition and predation.

\subsubsection{Loss of information from obfuscation of "revealed preferences"}

A more subtle cost of regulation is that it hides the information contained in a firm's choice. Firms, like any other economic agent, make decisions based on an analysis of the costs and benefits. Such decisions could relate to whether to disclose certain information, whether to obtain an audit, etc. By observing the choices that firms make with respect to financial reporting decisions (e.g., whether to get an audit), stakeholders can learn new and relevant information about firms. In other words, a firm's “revealed preferences” for disclosure (or non-disclosure) can convey information to stakeholders about firm type and its future prospects (e.g., Spence, 1973; Jensen and Meckling, 1976; Melumad and Thoman, 1990).

For example, while studies such as Blackwell, Noland, and Winters (1998) and Minnis (2011) attempt to control for the firm's voluntary selection of an audit, recent studies by Lennox and Pittman (2011) and Kausar, Shroff and White (2016) explicitly model the firm's choice 
(and, thus, control for the "treatment effect" of an audit). These studies find that observing a firm's choice to obtain a financial statement audit, per se, provides external financiers with incremental information about the firm, which helps reduce information asymmetry and financing frictions. Thus, regulation that forces firms to behave in a certain manner leads to a loss of information contained in the firm's choice.

\subsubsection{Negative externalities}

Although most of the empirical evidence suggests that disclosure has positive externalities, disclosure could also have negative externalities. For example, Fishman and Hagerty (1989) argue that increases in disclosure can attract investors away from other firms, resulting in lower price efficiency (if investors follow only a limited number of firms, e.g., due to limited attention and information processing costs). Durnev and Mangen (2009) provide evidence that when a firm discloses misleading information, other firms in the industry make suboptimal investment decisions based on those misleading disclosures.

\subsubsection{Implementation costs}

Finally, the act of operating and enforcing mandatory reporting requirements is costly, even if done efficiently. The benefits of regulation can only materialize if the rules are properly implemented and enforced. As a consequence, enforcement systems play a major role for reporting regulation (e.g., Daske, Hail, Leuz, and Verdi 2008; Christensen, Hail and Leuz 2016).

\subsection{What makes private companies different?}

The discussion to this point in Section 3 is not specific to private companies. However, private companies are different than public companies in terms of the agency problems they encounter. Since there is not a liquid secondary market that facilitates the transfer of security interests in private firms, the investor bases in private firms are relatively smaller and more 
stable over time compared to public firms. These size and stability differences facilitate the exchange of information among investors (as well as between managers and investors), reducing information asymmetry problems. In addition, private companies are often managed by the majority owner, creating little separation of ownership and control. ${ }^{17}$ Thus, what is one of the primary agency costs in a public firm - the separation of ownership and control - is less of a problem in private firms. ${ }^{18}$

It is far from obvious whether firms typically characterized with little separation of ownership and control accrue any benefits from the public disclosure of their financial statements. Specifically, the absence of separation in ownership and control reduces information asymmetry costs among owners, thereby limiting the importance of public disclosure to the disclosing firm. We emphasize "public" disclosure because clearly other stakeholders in a company such as debt holders, employees, suppliers and customers also demand financial information about the company. ${ }^{19}$ However, these stakeholders can efficiently obtain the company’s financial information via private channels (e.g., Cassar, Ittner and Cavalluzzo 2015; Minnis and Sutherland 2016). As a result, one of the primary motives for the public disclosure of corporate information - i.e., conveying information to outsider investors - is arguably less relevant in a private firms setting.

The fact that few private firms voluntarily disclose their financial statements to the public when there is not a mandate to do so (e.g., in countries like the U.S.) serves as one piece of

\footnotetext{
${ }^{17}$ It is important to emphasize, however, simply because a firm is private does not mean is has no separation of ownership and control. Lisowsky and Minnis (2016), for example, identify many private U.S. firms with dispersed ownership. Zimmerman (2015) and Gompers, Kaplan, and Mukharlyamov (2016) both suggest that private firms are more frequently opting for private equity ownership versus public equity (via initial public offering), leading to more private firms with separation of ownership and management.

${ }^{18}$ This is not to say that private firms do not have agency problems. A number of prior studies document agency costs and firm's responses to these costs in private firms (see e.g., Ball and Shivakumar 2005, Hope, Langli, and Thomas 2012, Hope, Thomas and Vyas 2013, Cassar, Ittner and Cavalluzzo 2015 among others).

${ }^{19}$ In addition, the process of preparing financial statements could be beneficial for the managers for internal decision making (e.g., McNichols and Stubben 2008; Shroff 2017). However, these benefits do not require firms to publicly disclose their financial statements.
} 
evidence that the private costs of disclosure exceed the private benefits when firms act unilaterally. Lisowsky and Minnis (2016) find that the majority of private firms in their sample (which is restricted to private firms with at least $\$ 10$ million in assets) prepare financial statements, often in accordance with GAAP. Yet, few of these firms, if any, disclose and disseminate their financial statements to the public. Bernard (2016) finds similar evidence among German private firms. Specifically, Bernard finds that the vast majority of private firms did not comply with a requirement to publicly disclosure financial statements until it was enforced in 2006. Thus, based on private firms' revealed preferences, it appears that private costs of disclosure exceed the benefits. ${ }^{20}$

If we take as given that private firms have few incentives for voluntary public disclosure and leave private firm financial reporting unregulated, research suggests this could potentially lead to an undersupply of disclosure from a social welfare perspective (because few private firms would publicly disclose their financial statements). Specifically, many of the benefits of financial reporting regulation apply broadly to all firms irrespective of whether they are public or private. Arguments in favor of regulation related to externalities, standardization (especially for lenders and other stakeholders such as customers/suppliers), and the reduction in duplicative negotiation costs apply broadly to both public and private firms. Thus, it is plausible that the economy wide costs of not requiring private firms to publicly disclose their financial statements are significant. But we rush to note that most of the costs of regulation discussed above apply to public and

\footnotetext{
${ }^{20}$ Of course, it is possible that the level of "voluntary" disclosure observed for U.S. private firms is downward biased because (i) private firms can free-ride on the disclosures provided by US public firms (e.g., Arif and De George 2016; Baginski and Hinson 2016; Breuer et al. 2016b) and (ii) firms with greatest proprietary costs stay private thereby creating a self-selected group of private firms with low disclosure incentives. Similarly, the German private firms in Bernard's sample are very small and might not have had a broad enough stakeholder group to benefit from public disclosure, making their voluntary disclosure behavior unrepresentative of the larger private firms with broader stakeholder bases. Thus, inferences based simply on observing the behavior of a group of firms is tenuous and needs to be interpreted cautiously.
} 
private firms, and thus, there still might not be a net benefit to financial reporting regulation. ${ }^{21}$ Much research is needed to further our understanding of the costs and benefits of private firm financial reporting regulation.

In addition to the above, another motivation for regulation is the protection of smaller stakeholders transacting with larger firms. Firms interact with many stakeholders besides its investors. If a stakeholder lacks the negotiating power to privately obtain a firm's financial statements, then disclosure regulation is potentially beneficial from an equality perspective. As such, if governments consider a level playing field as part of the social welfare criterion, then ensuring that stakeholders in weaker negotiating positions are not exploited by stronger firms could be a benefit of public disclosure mandates.

\section{Costs and benefits of financial reporting regulation: Evidence from the field}

\subsection{Survey methodology and sample}

To further our understanding of the costs and benefits of private firm financial reporting regulation, we developed two survey instruments to obtain the views of both the regulators and the regulated companies across countries. ${ }^{22}$ We will first discuss each of the survey designs and then we will discuss the results. The survey provided to accounting standard setters was four pages long and was distributed at the April 2016 meeting of the International Forum of Accounting Standard Setters (IFASS). This meeting was attended by representatives of the accounting standard setting bodies of 33 different countries and the International Accounting Standards Board (IASB). The survey included 15 questions, and several questions included subparts. We provided one paper-based survey to each contingent of representatives and asked

\footnotetext{
${ }^{21}$ Another difference between private and public firms that is perhaps relevant to the debate of whether to regulate private firms is that, on average, private firms are significantly smaller than public firms. Financial reporting regulation is disproportionately costly for small firms because complying with regulation has large fixed cost elements and, unlike larger firms, the small firms do not benefit from economies of scale.

${ }^{22}$ The description of our surveys in this section is minimized for parsimony; however, the survey instruments and additional details are available from the authors upon request.
} 
them to complete the survey during a meeting break. We received 25 completed surveys, of which 3 surveys belong to multiple participants from a country in attendance, and one belongs to the IASB member. Overall, we obtain the opinions of standard setters in 21 unique countries (out of 33) as well as the IASB. ${ }^{23}$

The second survey was sent to commercial firms in 34 European countries. The National Opinion Research Center (NORC) at the University of Chicago assisted with the online survey design, which was translated from English into four languages (French, Spanish, Italian, and German). In addition to the experts at NORC, we had several academics provide feedback about the survey questions and design. Moreover, multiple conversations with financial regulators and accounting standard setters informed our approach. The final survey included 25 items, presented in four sections. The data collection mode was web-only and took 15 minutes to complete, on average.

To generate the potential survey targets, we used the Bureau van Dijk (BvD) Amadeus and Financial Analysis Made Easy (FAME) data sets to compile a list of 6,847,355 firms with a valid value for at least one of the following variables: total assets, sales turnover, or number of employees. As Table 1 indicates, of these firms, 1,672,208 have email addresses listed in the data set. ${ }^{24}$ Column 4 from Table 1 indicates that the distribution of email addresses across country is not random-more than half of the firms from some of the major economies, such as the UK and Germany, have email addresses included, while other countries, such as Italy and France have a

\footnotetext{
${ }^{23}$ The list of 21 countries represented by standard setters who responded are: Austria, Belgium, Canada, Colombia, Netherlands, France, Germany, Hong Kong, India, Indonesia, Italy, Japan, Kenya, South Korea, Malaysia, Nepal, Norway, Pakistan, United Kingdom, United States.

${ }^{24}$ The distribution across countries is not the only non-random component to the email address availability. In untabulated results, we find that the average firm size is EUR 1.19 million for firms with email addresses and EUR 0.97 million for firms without, a statistically significant difference of EUR 229,000. We discuss additional descriptive statistics for participating firms in Section 4.2.
} 
substantially lower email participation rates. $^{25}$

Sample members were contacted via email and were then sent two reminders. Given the substantial number of email addresses, we randomly selected one-third of the valid email addresses $(557,160)$ from each country to send out the survey (ensuring that the final sample of email addresses included firms from all countries). In addition, emails were sent in batches with some time elapse between each batch. We adopted this approach to eliminate cloud-marking, which would effectively lead the internet service provider to classify these emails as spam.

Invitation emails were sent to the sample members from September 7 to September 21, 2016. The first batch of reminder emails were sent out to the sample members from September 22 until October 19, 2016; and the second batch of reminder emails were sent out from October 19 until November 8, 2016. Of the 557,160 unique emails, 15\% (or approximately 83,904 email addresses) were invalid or not used, and hence bounced back. Table 1 reports a total of 2,032 respondents provided at least one survey response. 1,477 respondents completed the entire survey.

There are several caveats and limitations to survey research, including ours. First, our response rate is $0.43 \%[=2,032 /(557,160-83,904)]$, which is low relative to other recent surveys of financial executives (e.g., Graham and Harvey 2001; Graham, Hanlon, Shevlin and Shroff 2014, 2017). It should be noted however that our survey was distributed via unsolicited email to individuals who were unaware of the survey and probably unaware of the organizations distributing the survey. ${ }^{26}$ By contrast, surveys in prior literature were sent using both email and mail to members of particular organizations. Therefore, our approach-using only email and broadly distributing the survey without regard for membership or attaching the survey to a

\footnotetext{
${ }^{25}$ According to a discussion with $\mathrm{BvD}$, the differential email participation rates across countries are caused by differential rules requesting this information.

${ }^{26}$ For example, the survey administrator at NORC received a number of emails from the survey recipients enquiring whether the survey invitation email was legitimate or just spam.
} 
recognizable organization - likely reduced our response rate considerably. Further, we used the email addresses provided in $\mathrm{BvD}$ and it is unclear whether those email addresses are regularly monitored by companies. Specifically, most of the email addresses in our dataset were quite generic (e.g., info@companyname.com) and, while we were able to trace the email addresses to actual company websites for a randomly selected group of firms, these email addresses may not be monitored frequently or may be monitored by individuals without the necessary knowledge to participate in the survey (e.g., sales personnel, customer service personnel).

Despite these limitations, we made our survey research design choices for several reasons. First was cost. We had a readily available list of emails and our survey design did not require printing or postage. Second, we wanted to cast our target frame as broadly as possible to minimize biases. If, for example, we selected a subset of firms belonging to a particular organization, then the responses we received may have only reflected the views of a particular segment of firms. Third, we chose not to affiliate the survey with a particular organization or regulatory body (i.e., send the invitation email from a recognizable email address) because we did not want participants to bias their responses towards a view of the regulators or be concerned that a governmental body was collecting the answers. Collectively, our response rate is likely lower than what we could have achieved had we targeted recipients more precisely, used a different form of survey (e.g., mail), or affiliated with a governmental body for recognition, but we decided not to do so to reduce cost and nonresponse bias. ${ }^{27}$

While we minimize nonresponse bias by our survey design, this is not to say our survey

\footnotetext{
${ }^{27}$ Another benchmark to compare our response rate and survey design is the survey conducted by CNA Interpreta for the European Commission in 2010 (CNA Interpreta 2011). This survey was specifically targeted to small-tomedium sized enterprises (SMEs) in 20 European countries and was also web-based. This survey had a higher response rate of approximately 60\%; however, it took a much more cost-intensive approach. It extended over 10 months (from January 2010 to October 2010) and involved more than 18,000 phone interviews to encourage and assist with survey participation. Ultimately, the CAN Interpreta survey collected 1,560 surveys, which is very similar to our final sample, which was collected at likely a fraction of the cost. These two approaches reflect various tradeoffs in survey design between cost and response rate.
} 
is free from selection issues. Several issues arise. First, as noted above, the datasets only provide email addresses for $24 \%$ of the firm-years, respectively. Moreover, the email addresses are not reported for a random sample of the firms in the dataset. Firms in the dataset with email addresses are typically larger than firms without email addresses. In addition, the distribution differs by country with some countries have greater representation than others. Second, firms do not randomly choose to complete the survey. Those firms that choose to complete the survey could be systematically different from those firms that do not. In addition, firms may not be responding completely truthfully or may have misunderstood the question we are asking. While there is no way to eliminate these issues, we attempt to mitigate them by having academics read the questions and employing a professional survey design firm. Just as important, a key feature of our survey design is that we are able to observe characteristics for all firms. We can compare firms that have email addresses in our data sets (and are thus eligible for participation) to those without email addresses. Conditional on having an email address, we can then compare the characteristics of firms that choose to respond to those firms that do not, which we discuss in the next section. Moreover, we do not argue that survey responses are independent of regulation. Regulation both shapes and is shaped by the opinions of the regulated. Our intent is not to disentangle this issue, but rather to provide descriptive evidence of the opinions of both the regulators and the regulated and assess as they conform to economic theories.

\subsection{Survey results}

Table 2 reports descriptive variables for the respondent firms. In panels A through C, we report total assets, turnover (i.e., sales revenue), and number of employees according to the BvD datasets, conditional on BvD collecting this information (thus, each variable has differing sample sizes). The panel A statistics are for firms that responded to the survey; panel B statistics are for those that were sent an email; panel C statistics are for firms that had an email address in BvD. 
The summary statistics of the firms across panels A, B, and C are similar, suggesting (i) the procedure to randomly select email addresses from the BvD database worked well (i.e., the firms in panels A and B are similar to those in panel C); and (ii) the firms that chose to respond, conditional on receiving an email, are economically similar in size to those that did not (i.e., the firms in panel A are similar to those in panel C), suggesting little nonresponse bias, at least in terms of firm size. ${ }^{28}$ As both a validity check and because BvD data is incomplete, we also asked firms to report to us their total assets, turnover, and number of employees using categorical partitions. This information is reported in Table 2, panels D through F. Collectively, all panels provide similar details: consistent with the overall distribution of firms in Europe, the typical respondent is small. The average total assets (turnover, employees) are 1.2 million EUR (1.7 million EUR, 18). Moreover, 55\% (49\%, 64\%) indicate that their firm fits into the smallest size category according to total assets (turnover, employees).

We next discuss the results of the surveys to both the accounting standard setters and companies. The survey instrument provided to the standard setters was slightly different from the one provided to the companies, but they contained several very similar questions. Therefore, throughout this discussion we report the results of both surveys in parallel. This approach facilitates a comparison of the perspectives-which often results in interesting contrasts. The surveys were partitioned into separate sections for disclosure and auditing and we follow that same framework in our discussion below.

\subsubsection{Perceptions on the net benefits of public disclosure of private firms}

Since private firms do not have significant dispersion in ownership, and can confidentially communicate their performance to stakeholders more directly, it is not ex ante

\footnotetext{
${ }^{28}$ In untabulated analyses, we also find that firms responding to the survey early in the process (before the median date of October 12) are observably similar firms to firms responding later in the survey process, further mitigating concerns about nonresponse bias.
} 
obvious whether there would be a net benefit of public disclosure for private firms. We included two questions in our survey to understand whether private firms derive any private or firm-level net benefits by publicly disclosing their financial statements. We first ask the company respondents if they file any financial results with a regulator or government entity, which is subsequently made public. In untabulated results, we find that 1,581 firms, or $78 \%$ of the sample, responded that they do. For those firms that responded in the affirmative, we ask several questions about their views on this requirement. ${ }^{29}$ We first attempt to discern if firms would prefer not to disclose. Table 3 reports that $62 \%$ of those firms that publicly disclose some financial information do so only because of the regulatory requirement. Moreover, only $2.6 \%$ of respondents indicate that they voluntarily disclose their financial results to the general public in the absence of a mandate; however, 33\% indicate that they would publicly disclose their financial information even if such disclosure was not required by law.

Next, we more directly ask both companies and standard setters whether public disclosure has a net benefit or cost using a scale of 1 (costs exceed benefits) to 5 (benefits exceed costs). Table 4 presents the results. We find the first of several contrasts between the views of the regulators and the regulated. ${ }^{30}$ While the majority of standard setters (52\%) view benefits of public disclosure exceeding the costs, very few private firms (16\%) agree that the benefits of public disclosure exceed the costs. Collectively, the results in Tables 3 and 4 are generally consistent with public disclosure being privately costly, on net, for most private firms.

\footnotetext{
${ }^{29}$ The web survey instrument allowed certain respondents to proceed to the subsequent questions even though they did not answer "yes" to the public disclosure question. Therefore, the sample size for the questions about public disclosure $(1,659)$ is greater than the number of firms answering "yes." More generally, each question received a somewhat different number of responses based on respondent participation.

${ }^{30}$ While we attempted to phrase the questions to minimize interpretation differences between standard setters and companies, it is important to note that differences in the responses between these respondent groups could be the result of differential interpretation of the question. For example, while we asked the standard setters to only consider the net costs and benefits of public disclosure to a private firm, they may have still responded by considering society's collective costs and benefits. They may have also been considering the views of larger companies—we did not specify firm size to the standard setters.
} 


\subsubsection{Perceptions on which stakeholders benefit of public disclosure of private firms}

We take two approaches to understand which stakeholders are perceived to benefit from the public disclosures of private firms. We first provide a list of various stakeholders and ask how likely it is for the particular stakeholder to download a firm's public financial information. We then ask firms about their own download activity. Table 5 reports the results for the question of how likely particular stakeholders are to download a firm's financial statements. Both companies and standard setters were asked this question. Consistent with the views from Table 4 that standard setters generally view public disclosure as more beneficial than companies, standard setters responded that stakeholders are much more likely to download public financial reports than the firms themselves reported. For some stakeholders (e.g., potential shareholders, customers, and employees), standard setters were twice as likely to suggest that a firm's financial report would be downloaded. While standard setters view the likelihood of download as much higher than firms, it is interesting to note that the two contingents were generally consistent in the rank ordering of the likelihood of download across the stakeholders. Specifically, both respondent groups view lenders and competitors as the stakeholders most likely to use public reports. The lender result is consistent with prior research that finds that banks use financial reports from borrowers (e.g., Collis and Jarvis 2002, Collis 2008, Cassar, Ittner, and Cavalluzo 2015, Breuer et al. 2016a, Minnis and Sutherland 2016).

That competitors benefit from observing a firm's financial statements is consistent with the academic literature suggesting both a cost and benefit of public disclosure-and both firms and standard setters view competitors as likely users of firms' financial reports. On the one hand, to the extent a firm's disclosures are used by peer firms and competitors to better understand the overall economic condition in which they operate, the benefit of a firm's public disclosure to its competitors is not necessarily costly for the disclosing firm. That is, if a firm's disclosure helps 
reduce overall economic uncertainty, peer firms (including competitors) would benefit from the reduced uncertainly, which helps all firms make better decisions (Dixit and Pindyck 1994). On the other hand, much research highlights proprietary costs of disclosure-i.e., firms disclose proprietary information that competitors exploit at the expense of the disclosing firm (see e.g., Verrecchia 1983; Leuz 2004; Botosan and Stanford 2005; Berger and Hann 2007 among others).

Dedman and Lennox (2009) find that managers are more likely to withhold information about sales and costs if they perceive that current or potential competition is strong. However, Badertscher et al. (2013) suggest that peer firms learn from one another, improving investment efficiency, creating a benefit of public disclosure. A necessary condition for the inference in Badertscher et al. (2013) is that peers actual read each other's reports. Our survey evidence provides direct support that this is the case. This result is reinforced in Table 6. We ask the company respondents if they have ever downloaded the reports of other firms. Competitors received the most “yes” responses (48\%).

An important source of finance for small private firms such as those we survey is trade credit (Rajan and Zingales 1995; Berger and Udell 1997). Recent studies such as Costello (2014), Hope, Thomas and Vyas (2016), and Lisowsky and Minnis (2016) find empirical evidence in a U.S. setting that suppliers/customers value a firm's financial statements. Supporting the view that customers/suppliers are significant users of financial reports (either for trade credit or for better understanding the overall economic environment), we find that (i) $46 \%$ (29\%) of the companies believe that their suppliers (customers) view their financial statements (see table 5) and (ii) 37\% (46\%) of the companies report that they download the financial reports of their suppliers (customers) (see table 6).

One additional result is worth discussing from Table 5: standard setters and companies appear to have starkly different views with respect to whether employees benefit from public 
financial reporting. Forty-two percent of standard setters believe that employees are likely to download their company's financial reports, while only $12 \%$ of company respondents share this view. The extent to which employees benefit from the public disclosure of their employer's financial statements is an interesting area for future research.

We next dig further into the proprietary costs hypothesis and identify specific concerns. We ask respondents what aspects of public disclosure are concerning to them, on a scale of 1 (none) to 5 (very important). As discussed in Section 3, academic literature has identified at least two concerns vis-à-vis competition: competitors learning about a firm's innovations and high margin opportunities (which we refer to as "performance") and competitors learning about a firm's financial constraints (which we refer to as “leverage” or debt level). We also ask about trade partners, neighbors, and direct compliance costs. Table 7 reports that competitive concerns-both performance and financial constraints-are the most salient concerns. Supporting the results of Bernard (2016), financial constraints are ranked by the firms as the most important disclosure concern. Interestingly, compliance with the public disclosure regulation is considered a more important concern by standard setters (40\%) than the firms themselves (30\%).

To summarize the results from the questions relating to disclosure, we find general support for the theories suggesting firms experience private costs and significantly lower private benefits from the public disclosure of their financial statements. On net, firms report that they would prefer not to publicly disclose their financial results, which is consistent with the behavior of private firms in the U.S. Standard setters generally disagree with this view. On average, their view of public disclosure is that the benefits outweigh the costs and generally report that there is more broad use of financial reports compared to the firms.

\subsubsection{Perceptions on the net benefits of financial auditing}


We next ask firms and standard setters about their perspectives on the second dimension of financial reporting regulation: financial audits. We begin by asking firms whether they purchased an audit of their financial statements. ${ }^{31}$ In untabulated results, 778 out of the 1,261 firms $(62 \%)$ responding to the question indicate that their financial statements were audited. ${ }^{32}$ We then asked the 778 audited firms to what extent a regulatory mandate was binding. Table 8 reports that $32 \%$ of the audited firms are receiving audits only because of the mandate. The majority, approximately 65\%, would still have their financial statements audited regardless of a mandate. ${ }^{33}$ Given the similarity of survey question related to the net benefit of an audit (whose results are reported in Table 8) to that of the question related to the net benefits of public disclosure (whose results are reported in Table 3), it is worth comparing the results of these tables. The "voluntary" compliance rate of auditing is substantially higher (40\%) than public disclosure (19\%). ${ }^{34}$ This result suggests that auditing mandates are less binding than disclosure mandates, which is consistent with the significant literature indicating private benefits of financial statement audits to private firms.

In Table 9 we compare companies' and standard setters' views of auditing. Consistent with standard setters viewing compliance with financial reporting standards as an important outcome, $75 \%$ of the respondents indicated that the benefits of an audit exceed the cost. Only $28 \%$ of company respondents indicated that the benefits of an audit exceed the costs. However,

\footnotetext{
${ }^{31}$ Our initial set of questions ask about the use of outside accountants more generally. In untabulated results, we find that 1,371 respondents (86\%) used an accounting firm at some point during the years 2013 to 2015. Of those that used an accountant, 1,303 (96\%) indicated that the accountant was used to help prepare and file taxes. Collectively, the respondents use accounting firms at a very high rate.

3295 respondents indicated that they did not know whether their financial statements were audited.

${ }^{33}$ This rate is similar to the responses in a 1999 survey of directors for small U.K. firms in Collis, Jarvis, and Skerratt (2004). Further, this result is also consistent with the rate of voluntary audits received by firms that are exempt from the audit (see Lennox and Pittman 2011 and Kausar et al. 2016).

${ }^{34}$ These percentages are calculated as follows. For auditing: $(38.7 \%+26.0 \%)=64.7 \%$ x $778=503$ firms that would purchase an audit in the absence of regulation. Divide 503 by 1,261 (total number of firms asked about auditing) = $40 \%$ of total firms would purchase an audit. For disclosure: $(33.2 \%+2.6 \%)=35.8 \% \times 1,659=594$ firms that disclose their financial reports in the absence of regulation. Divide 594 by 2,032 (total number of firms asked about disclosure $)=19 \%$ of total firms would disclose.
} 
$67 \%$ of the respondents indicate that the benefit of an audit is equal to or greater than the cost of an audit (which is consistent with the 65\% of respondents in Table 8 reporting that they would continue to purchase an audit in the absence of a mandate). Table 10 examines which factors are the most important considerations for firms in assessing whether an audit is net beneficial. The direct costs (i.e., auditor fees) are the most important concern, followed by the use of management's time involved in an audit. The idea that audits lack any benefits is not as an important concern as the costs. Nevertheless, it is interesting to note that $42 \%$ of firms view audits as providing few benefits.

We then asked the audited firms and the standard setters which set of stakeholders likely benefits from a firm's financial statement audit. Table 11 reports the results. Again, consistent with the results of public disclosure (Table 5), standard setters generally perceive auditing regulation to be more valuable than firms do; however, once again, the relative ranking of which stakeholders benefit from an audit is similar from both respondent groups. Both view capital providers (equity and debt) as beneficiaries of an audit, consistent with theories predicting private benefits of an audit in mitigating information asymmetry and facilitating capital allocation (e.g., Watts and Zimmerman 1983). Both also view government regulators and tax authorities as benefiting from a financial statement audit. Quite a few open ended responses from both standard setters and companies suggest that accounting auditors in Europe essentially serve as compliance monitors. We view the extent to which privately contracted auditors serve as compliance monitors across countries as an interesting avenue for future investigation.

Table 11 also reports that standard setters and firms have differing views on the benefit of a financial statement audit to employees. As with public disclosure, firms view employees as receiving very little benefit from an audit of the firm's financial statement. Relative to other stakeholders, both standard setters and firms view competitors as receiving little benefit for a 
firm purchasing an audit, which contrasts with public disclosure benefits. This suggests that competitors do not require audited information (which is more precise and credible) to benefit from peers' financial reports.

We conclude the survey evidence by asking both firms and standard setters to explicitly contrast their country's regulations to the approach of the U.S., in which regulations for private company financial reporting are essentially absent. We first ask whether financial statement audits should be completely voluntary and then ask whether disclosures should be completely voluntary. Table 12 tabulates the results. Given the evidence presented up to this point, it is not surprising that standard setters overwhelmingly disagree with the idea of eliminating regulation and that this view is much more strongly held compared to firms. More interesting is that while the majority of firms believe the audit decision should be completely voluntary, the majority of firms believe that public reporting should be mandatory.

In sum, both firms and standard setters suggest a benefit of financial statement audits to firms. Moreover, perhaps not surprisingly, firms view financial statement audits as relatively more beneficial than public disclosure (as revealed by the proportion that would continue the activity in the absence of regulation).

\section{Discussion and conclusion}

Private firms face vastly different financial reporting regulations around the world. In a few countries, the United States and Canada, for example, the financial reporting regulatory environment for private firms is quite lax. Firms are not required to report their results publicly nor have their financial statements audited. In Europe, by contrast, many private firms with limited liability are required to do both. In this paper we discuss the definition of a private firm, review theoretical arguments for and against regulating the disclosure and auditing of private firm financial reports and the empirical evidence investigating those theories, and provide new 
survey evidence highlighting the viewpoints of the both the regulators (standard setters) and the regulated (private firms in Europe).

The evidence is consistent with theory in most, but not all respects: individually, firms perceive limited benefits from public disclosure and have proprietary costs. The majority of firms would not continue to disclose their financial results publicly if the regulation was removed. However, the evidence also reveals support for the benefits of public disclosure. Firms reveal that they download the financial reports of competitors, suppliers and customers, and believe that their competitors/suppliers/customers do the same. Moreover, while most firms would not reveal their financial reports if given the option, the majority still believe that public disclosure should be required. We think these perspectives reveal the positive externalities of mandated disclosure. While public disclosure may not be net beneficial to the disclosing private firm, it is collectively beneficial as a result of an improved information environment.

The views of a financial statement audit mandate are different from the views of public disclosure. The majority of firms that currently have financial statement audits report that they would continue to purchase one in the absence of regulation because of the private capital market benefits, for example (e.g., better access to bank debt). Yet, the majority of firms state that they prefer not to have an audit mandate. In contrast to public reporting, the audit mandate appears to have limited public benefit (such as an overall improved information environment). The primary public benefit of an audit appears to be to ensure compliance (i.e., outsourced governmental monitoring), but that the majority of firm respondents did not think this is sufficient to justify a mandate. Auditor fees and management time are the primary concerns for the audit mandate, but interestingly, a significant minority of firms did not perceive any benefit from an audit. Of course, our survey results need to have the caveat that the majority of respondents are small firms. 
Having reviewed the theory and evidence, where do we stand on regulations mandating the disclosure and auditing of private firms' financial reports? The evidence is far from clear to state the optimal level of financial reporting regulation. Evidence supports benefits for public disclosure, for example, but are the benefits sufficient to offset the costs? The U.S. and Canadian regimes have little financial reporting regulation and we are unaware of evidence that these respective economies are at a disadvantage because of this. By contrast, under the European model firms are able to take advantage of positive externalities, but perhaps firms make less investment ex ante because of proprietary cost concerns, for example. Ultimately, we think this is a fascinating, important, and fundamental question for research to tackle. This survey of the literature and opinions of those involved in the regulatory process is only a start and much research is still needed to help understand the causes and consequences of private company reporting and, ultimately, the optimal level of regulation. 


\section{References}

Admati, A. and P. Pfleiderer. 2000. Forcing Firms to Talk: Financial Disclosure Regulation and Externalities. Review of Financial Studies 13(2): 479-519.

Allee, K. and T. Yohn. 2009. The Demand for Financial Statements in an Unregulated Environment: An Examination of the Production and Use of Financial Statements by Privately Held Small Businesses. The Accounting Review 84(1): 1-25.

Aobdia, D. and N. Shroff. 2017. Regulatory Oversight and Auditor Market Share. Unpublished working paper, MIT Sloan School of Management.

Arif, S. and E. De George. 2016. When does interim earnings news travel around the world? Unpublished Results, Indiana University and London Business School.

Baginski, S. and L. Hinson. 2016. Cost of Capital Free-Riders. The Accounting Review 91(5): 12911313.

Ball, R., and L. Shivakumar. 2005. Earnings quality in UK private firms: comparative loss recognition timeliness. Journal of Accounting and Economics 39 (1): 83-128.

Badertscher, B., N. Shroff, and H. White. 2013. Externalities of Public Firm Presence: Evidence from Private Firms’ Investment Decisions. Journal of Financial Economics 109(3): 682-706.

Beatty, A., B. Ke, and K. Petroni. 2002. Earnings Management to Avoid Earnings Declines across Publicly and Privately Held Banks. The Accounting Review 77(3): 547-570.

Berger, P. and R. Hann. 2007. Segment Disclosure and the Proprietary and Agency Costs of Disclosure. The Accounting Review 82(4): 869-906.

Berger, A. N. and G. F. Udell. 1998. The Economics of Small Business Finance: The Roles of Private Equity and Debt Markets in the Financial Growth Cycle. Journal of Banking and Finance 22: 613-673.

Bernard, D. 2016. Is the Risk of Product Market Predation a Cost of Disclosure? Journal of Accounting and Economics 62(2-3): 305-325.

Bernard, D., D. Burgstahler, and D. Kaya. 2015. Size Management by European Private Firms to Minimize Disclosure and Audit Costs. Available at SSRN: https://ssrn.com/abstract $=2484161$ or http://dx.doi.org/10.2139/ssrn.2484161

Blackwell, D., T. Noland, and D. Winters. 1998. The Value of Auditor Assurance: Evidence from Loan Pricing. Journal of Accounting Research 36(1): 57-70.

Botosan, C., Stanford, M., 2005. Managers' motives to withhold segment disclosures and the effect of SFAS No. 131 on analysts' information environment. The Accounting Review 80, 751-771.

Breuer, M., Hombach, K., Müller, M.A., 2016a. Firms’ Public Disclosure and Banking: Evidence from Disclosure Regulation. Working paper.

Breuer, M., Hombach, K., Müller, M.A., 2016b. When you talk, I remain silent: Spillover effects of peers' mandatory disclosures on firms' voluntary disclosures. Working paper.

Bushee, B. and C. Leuz. 2005. Economic Consequences of SEC Disclosure Regulation: Evidence from the OTC Bulletin Board. Journal of Accounting and Economics 39(2): 233-264.

Burgstahler, D., Hail, L., Leuz, C., 2006. The importance of reporting incentives: earnings management in European private and public firms. The Accounting Review 81, 983-1016.

CNA Interpreta. 2011. Study on Accounting Requirements for SMEs. Contract SI2ACPROCE030483800. Directorate-General for Enterprise and Industry.

Cassar, G., C, Ittner, and K. Cavalluzzo. 2015. Alternative information sources and information asymmetry reduction: evidence from small business debt. Journal of Accounting and Economics 59: 242-263.

Christensen, H., L. Hail, and C. Leuz. 2016. Capital-Market Effects of Securities Regulation: Prior Conditions, Implementation, and Enforcement. Review of Financial Studies 29(11): 2885-2924.

Coase, R. 1960. The Problem of Social Cost. Journal of Law and Economics 3: 1-44. 
Collis, J. 2008. Directors' Views on Accounting and Auditing Requirements for SMEs. Department for Business Enterprise and Regulatory Reform, London.

Collis, J. 2010. Audit Exemption and the Demand for Voluntary Audit: A Comparative Study of the UK and Denmark. International Journal of Auditing 14: 211-231.

Collis, J. 2012. Determinants of Voluntary Audit and Voluntary Full Accounts in Micro- and nonmicro Small Companies in the UK. Accounting and Business Research 42(4): 441-468.

Collis, J. and R. Jarvis. 2002. Financial information and the management of small private companies. Journal of Small Business and Enterprise Development 9: 100-110.

Collis, J., R. Jarvis, and L. Skerratt. 2004. The Demand for the Audit in Small Companies in the UK. Accounting and Business Research 34(2): 87-100.

Costello, A. 2014. Trade Credit Policy in Long-Term Supply Contracts. Working paper.

Daske, H., L. Hail, C. Leuz, and R. Verdi. 2008. Mandatory IFRS Reporting Around the World: Early Evidence on the Economic Consequences. Journal of Accounting Research 46(5): 10851142.

De George, E., X. Li, and L. Shivakumar. 2016. A Review of the IFRS Adoption Literature. Review of Accounting Studies 21(3): 898-1004.

Dechow, P., W. Ge, and C. Schrand. 2010. Understanding Earnings Quality: A Review of the Proxies, their Determinants, and their Consequences. Journal of Accounting and Economics 50 (2-3): 344-401.

Dedman, E., and C. Lennox. 2009. Perceived competition, profitability, and the withholding of information about sales and the cost of sales. Journal of Accounting and Economics 48 (2/3): 210-230.

DeFond, M., X. Hu, M. Hung, and S. Li. 2011. The Impact of Mandatory IFRS Adoption on Foreign Mutual Fund Ownership: The Role of Comparability. Journal of Accounting and Economics 51(3): 240-258.

Dixit, A. and R. Pindyck. 1994. Investment Under Uncertainty (Princeton, NJ: Princeton University Press).

Durnev, A. and C. Mangen. 2009. Corporate Investments: Learning from Restatements. Journal of Accounting Research 47(3): 679-720.

Dye, R. Mandatory versus voluntary disclosures: The Cases of Financial and Real Externalities The Accounting Review 65(1): 1-24.

Easterbrook, F. and D. Fischel. 1984. Disclosure and the Protection of Investors. Virginia Law Review 70(4): 669-715.

Financial Accounting Standards Board (FASB). 2013. Definition of a Public Business Entity. No. 2013-12. December 2013.

Florou, A. and P. Pope. 2012. Mandatory IFRS Adoption and Institutional Investment Decisions. The Accounting Review 87(6): 1993-2025.

Gompers, P., S. Kaplan, and V. Mukharlyamov. 2016. What Do Private Equity Firms Say They Do? Journal of Financial Economics 121(3): 449-476.

Graham, J. and C. Harvey. 2001. The Theory and Practice of Corporate Finance: Evidence from the Field. Journal of Financial Economics 60(2-3): 187-243.

Graham, J., M. Hanlon, T. Shevlin, and N. Shroff. 2014. Incentives for Tax Planning and Avoidance: Evidence from the Field. The Accounting Review 89(3): 991-1023.

Graham, J., M. Hanlon, T. Shevlin, and N. Shroff. 2017. Tax Rates and Corporate Decision Making. Review of Financial Studies, forthcoming.

Granja, J. 2016. Disclosure Regulation in the Commercial Banking Industry: Lessons from the National Banking Era. Working paper.

Grossman, S. 1981. The Informational Role of Warranties and Private Disclosure about Product Quality. The Journal of Law and Economics 24(3): 461-483. 
Healy, P. and J. Wahlen. 1999. A review of the earnings management literature and its implications for standard setting. Accounting Horizons 17, 365-383.

Hope, O.-K., J. Langli, and W. Thomas. 2012. Agency Conflicts and Auditing in Private Firms. Accounting, Organizations, and Society 37 (7): 500-517.

Hope, O.-K., W. Thomas, and D. Vyas. 2013. Financial Reporting Quality in U.S. Private and Public Firms. The Accounting Review 88 (5): 1715-1742.

Hope, O.-K., W. Thomas, and D. Vyas. 2016. Stakeholder Demand for Accounting Quality and Economic Usefulness of Accounting in U.S. Private Firms Journal of Accounting and Public Policy, forthcoming.

Jensen, M. and W. Meckling. 1976. Theory of the Firm: Managerial Behavior, Agency Costs, and Ownership Structure. Journal of Financial Economics 3: 305-360.

Katz, S. Earnings Quality and Ownership Structure: The Role of Private Equity Sponsors. The Accounting Review 84(3): 623-658.

Kausar, A., N. Shroff, and H. White. 2016. Real Effects of the Audit Choice. Journal of Accounting and Economics 62(1): 157-181.

Kothari, S.P., K. Ramanna, and D. Skinner. 2010. Implications for GAAP from an Analysis of Positive Research in Accounting. Journal of Accounting and Economics 50 (2-3): 246-286.

Lambert, R., C. Leuz, and R. Verrecchia. 2007. Accounting Information, Disclosure, and the Cost of Capital. Journal of Accounting Research 45(2): 385-420.

Lennox, C. and B. Li. 2012. The consequences of protecting audit partners' personal assets from the threat of liability. Journal of Accounting and Economics 54, 154-173.

Lennox, C. and J. Pittman. 2011. Voluntary Audits versus Mandatory Audits. The Accounting Review 86(5): 1655-1678.

Leuz, C. 2004. Proprietary versus Nonproprietary Disclosures: Evidence from Germany. In: The Economics and Politics of Accounting: International Perspectives on Research Trends, Policy, and Practice. Oxford University Press.

Leuz, C. 2010. Different Approaches to Corporate Reporting Regulation: How Jurisdictions Differ and Why. Accounting and Business Research 40(3): 229-256.

Leuz, C., A. Triantis, and T. Wang. 2008. Why do Firms go Dark? Causes and Economic Consequences of Voluntary SEC Deregistrations. Journal of Accounting and Economics 45: 181208.

Leuz, C. and J. Wustemann. 2004. The Role of Accounting in the German Financial System. Published in "The German Financial System," J. Krahnen and R.H. Schmidt (eds.), Oxford University Press.

Leuz, C. and P. Wysocki. 2016. The Economics of Disclosure and Financial Reporting Regulation: Evidence and Suggestions for Future Research. Journal of Accounting Research 54(2): 525-622.

Lisowsky, P. and M. Minnis. 2016. Accounting Choices and Capital Allocation: Evidence from Large Private U.S. Firms. Working paper, University of Chicago and University of Illinois.

Mahoney, P. 1995. Mandatory Disclosure as a Solution to Agency Problems. The University of Chicago Law Review 62(3): 1047-1112.

McNichols, M. and S. Stubben. 2008. Does Earnings Management Affect Firms' Investment Decisions? The Accounting Review 83(6): 1571-1603.

Melumad, N. and L. Thoman. 1990. On Auditors and the Courts in an Adverse Selection Setting. Journal of Accounting Research 28(1): 77-120.

Mian, S. and C. Smith. 1990. Incentives Associated with Changes in Consolidated Reporting Requirements. Journal of Accounting and Economics 13: 249-266.

Minnis, M. 2011. The Value of Financial Statement Verification in Debt Financing: Evidence from Private U.S. Firms. Journal of Accounting Research 49(2): 457-506.

Minnis, M. and A. Sutherland. 2016. Financial Statements as Monitoring Mechanisms: Evidence 
from Small Commercial Loans. Journal of Accounting Research, forthcoming.

Peltzman, S. 1976. Toward a More General Theory of Regulation. Journal of Law and Economics 19: 211-240.

Polinsky, A. M. 1980. Resolving Nuisance Disputes: The Simple Economics of Injunctive and Damage Remedies. Stanford Law Review 32(6): 1075-1112.

Rajan, R. and L. Zingales. 2003. The great reversals: the politics of financial development in the 20th century. Journal of Financial Economics 69: 5-50.

Rajan, R. and L. Zingales. 1995. What Do We Know about Capital Structure? Some Evidence from International Data. Journal of Finance 50(5): 1421-1460.

Ross, S. 1979. Disclosure Regulation in Financial Markets: Implications of Modern Finance Theory and Signaling Theory. Issues in Financial Regulation 5 (1979): 177-202.

Shavell, S. 1986. The judgment proof problem. International Review of Law and Economics 6: 4558.

Shroff, N. 2016. Discussion of: "Is the Risk of Product Market Predation a Cost of Disclosure?" Journal of Accounting and Economics 62(2-3): 326-332.

Shroff, N. 2017. Corporate Investment and Changes in GAAP. Review of Accounting Studies, 22(1): $1-63$.

Shroff, N., R. Verdi, and B. Yost. 2017. When does the Peer Information Environment Matter? Working paper. MIT.

Shroff, N., R. Verdi, and G. Yu. 2014. Information Environment and the Investment Decisions of Multinational Corporations. The Accounting Review 89(2): 759-790.

Solomon, S.D. 2011. Facebook may be forced to go public amid market gloom. New York Times, Nov. 29, 2011. Accessed via http://dealbook.nytimes.com/2011/11/29/facebook-may-be-forcedto-go-public-amid-market-gloom/?_r=0 on Nov. 28, 2016.

Spence, M. 1973. Job Market Signaling. Quarterly Journal of Economics 87(3): 355-374.

Stigler, G. 1971. The Theory of Economic Regulation. Bell Journal of Economics and Management Science 2(1): 3-21.

Watts, R. and J. Zimmerman. 1983. Agency problems, auditing, and the theory of the firm: Some evidence. Journal of law and Economics, 613-633.

Yu, G. and A. Wahid. 2014. Accounting Standards and International Portfolio Holdings. The Accounting Review 89(5): 1895-1930.

Zimmerman, J. 2015. The Role of Accounting in the Twenty-first Century Firm. Accounting and Business Research 45(4): 485-509.

Zingales, L. 2009. The Future of Securities Regulation. Journal of Accounting Research 47(2): 391425. 
Figure 1

“The Accounting Matrix” from Can Interpreta (2011, p. 17)

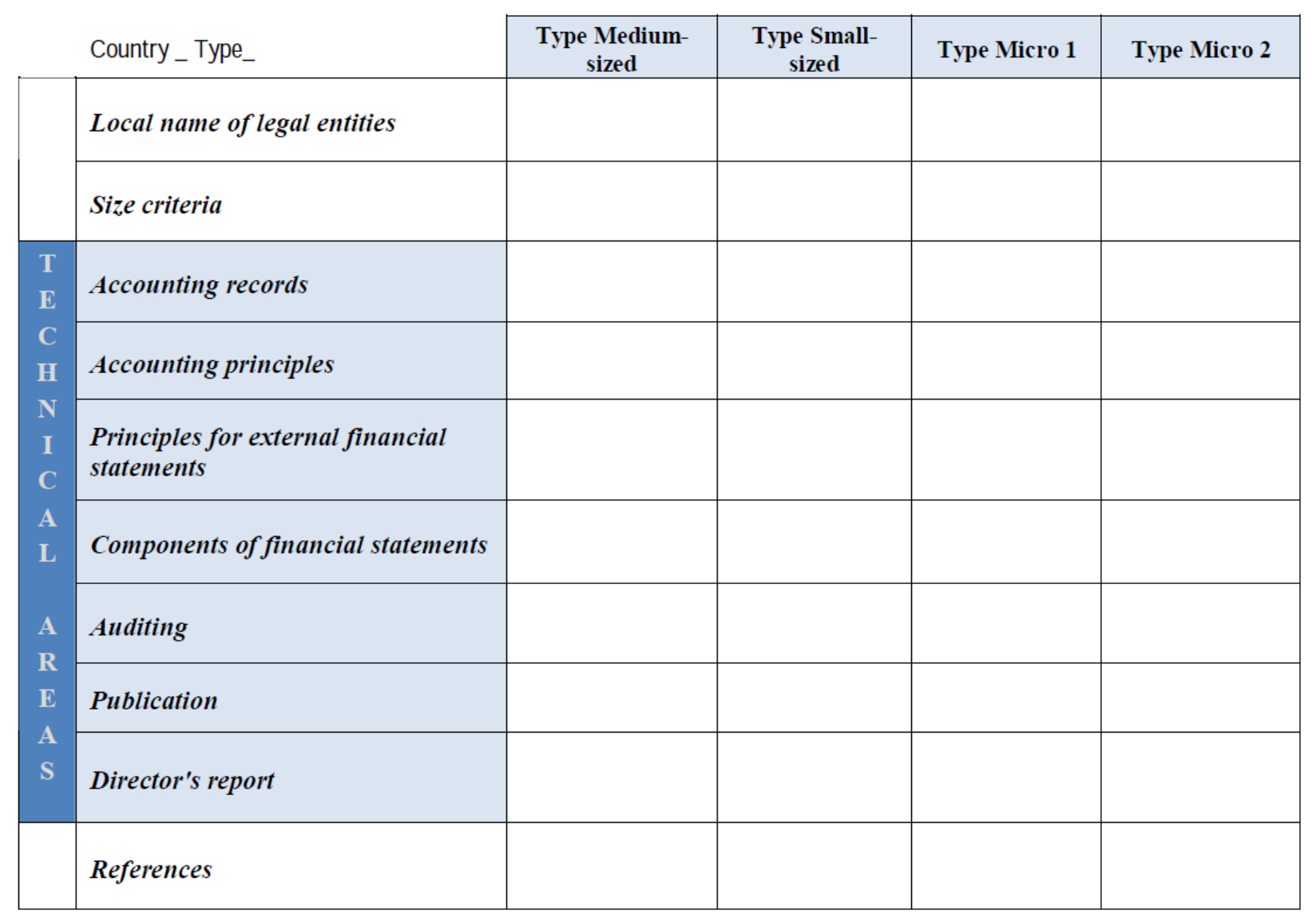


Figure 2

Financial disclosure and auditing firm size thresholds for nine European countries for the years 2003 and 2011 from Bernard et al. (2015) Appendix C.

Panel A: Size thresholds for disclosure requirements
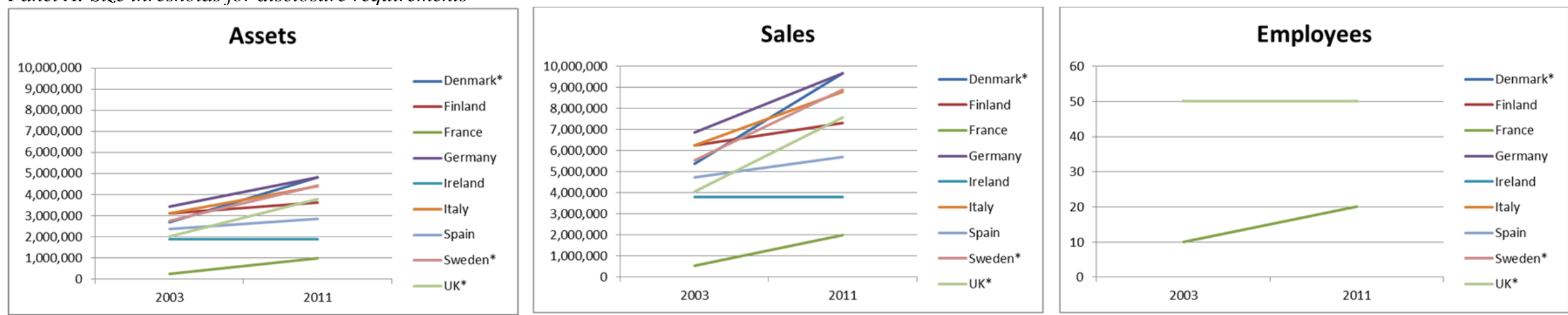

Panel B: Size thresholds for audit requirements

\begin{tabular}{|c|c|c|}
\hline \multicolumn{3}{|c|}{ Assets } \\
\hline \multirow{9}{*}{$\begin{array}{r}10,000,000 \\
9,000,000 \\
8,000,000 \\
7,000,000 \\
6,000,000 \\
5,000,000 \\
4,000,000 \\
3,000,000 \\
2,000,000 \\
1,000,000\end{array}$} & & \multirow{2}{*}{ —Denmark* } \\
\hline & & \\
\hline & & —Finland \\
\hline & & —France \\
\hline & & —Germany \\
\hline & 证 & _Ireland \\
\hline & $=$ & _Italy \\
\hline & $=$ & \\
\hline & & - Sweden* \\
\hline 0 & - & $-\mathrm{UK}^{*}$ \\
\hline
\end{tabular}
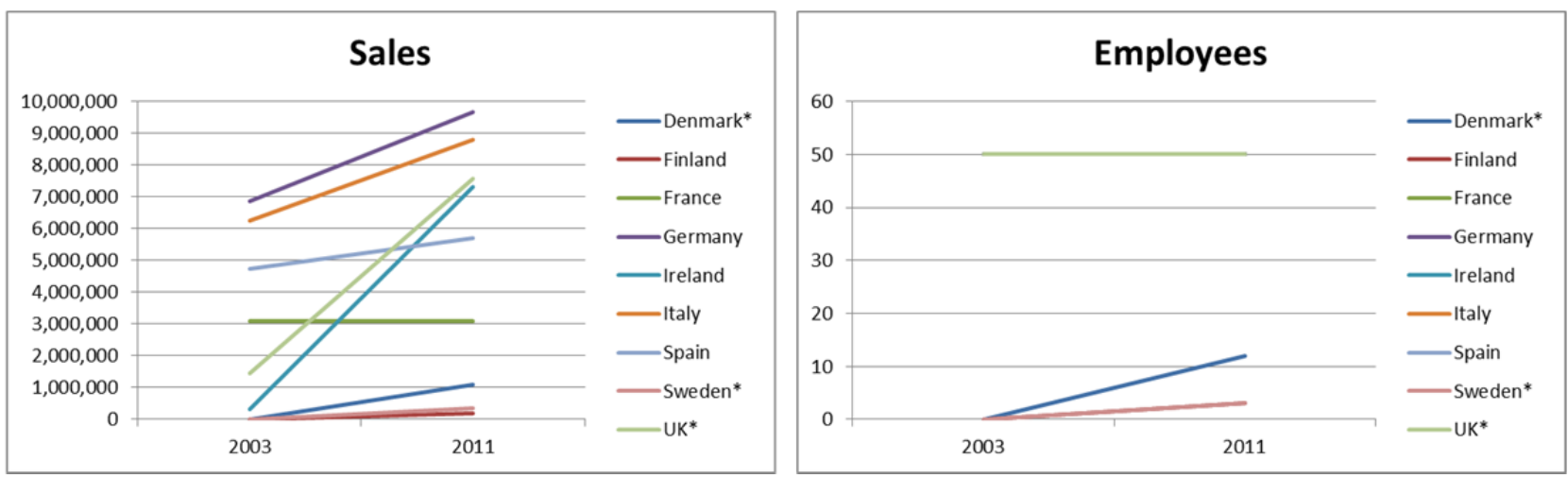
TABLE 1

Survey sample selection and participation by country

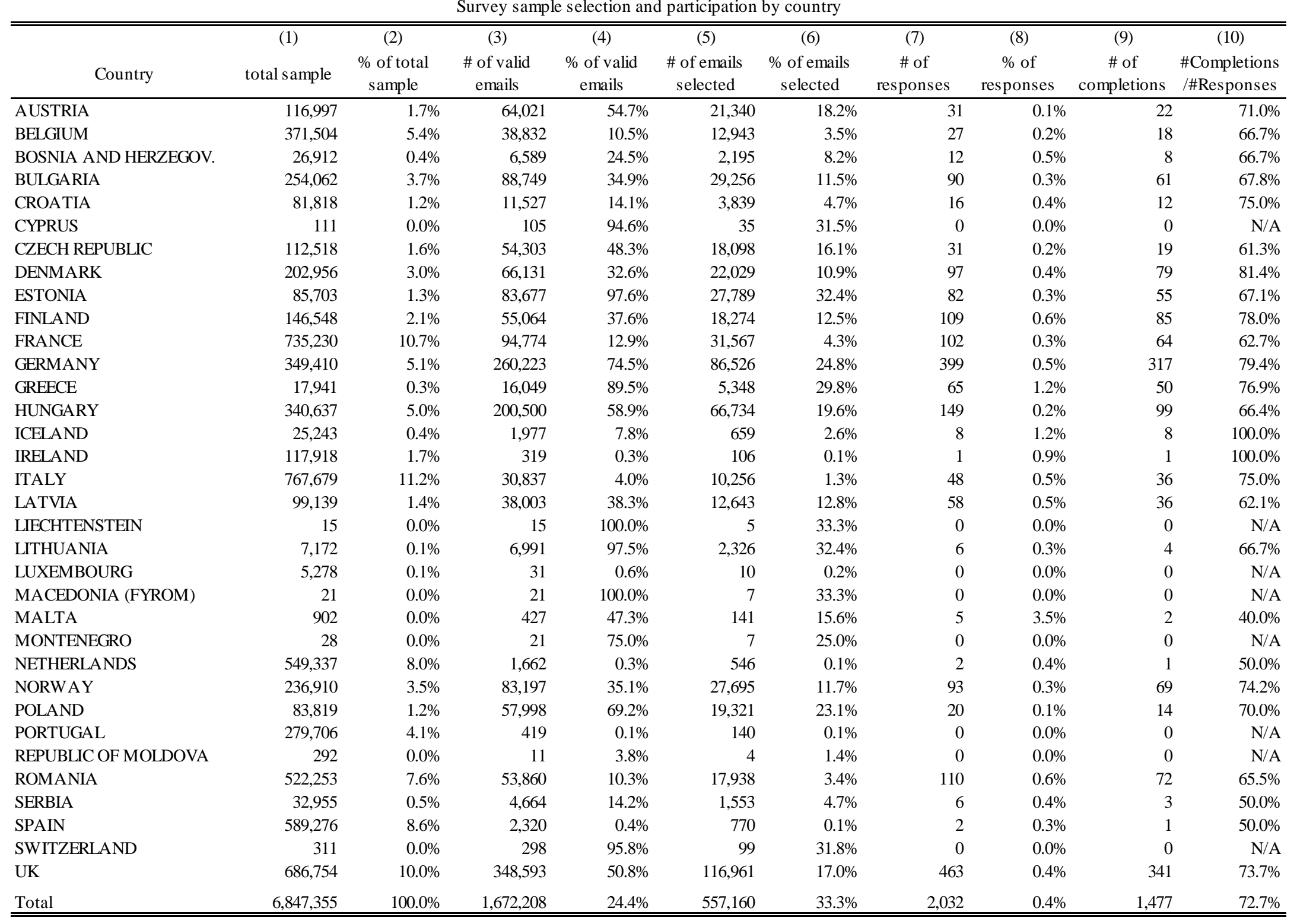


TABLE 2

Descriptive statistics for participating and non-participating firms

(Total assets and Turnover in 000's EUR)

\begin{tabular}{|c|c|c|c|c|c|c|c|}
\hline \multicolumn{8}{|c|}{ Panel A: Conditional on responding } \\
\hline & Mean & Min & 25th & 50th & 75th & Max & $\mathbf{n}$ \\
\hline Total assets & $1,163.8$ & 0.0 & 3.7 & 108.0 & 659.7 & $95,695.0$ & 2,021 \\
\hline Turnover & $1,673.0$ & 0.0 & 22.7 & 214.4 & $1,270.0$ & $83,729.0$ & 1,273 \\
\hline Employees & 17.9 & 0.0 & 1.0 & 4.0 & 13.0 & $1,874.0$ & 886 \\
\hline
\end{tabular}

Panel B: Conditional on receiving email

\begin{tabular}{|c|c|c|c|c|c|c|c|}
\hline & Mean & Min & 25th & 50th & 75th & Max & $\mathbf{n}$ \\
\hline Total assets & $1,178.8$ & 0.0 & 4.9 & 102.6 & 752.4 & $4,212,000.0$ & 553,089 \\
\hline Turnover & $1,594.7$ & 0.0 & 19.1 & 174.7 & $1,290.4$ & $1,868,000.0$ & 350,932 \\
\hline Employees & 30.5 & 0.0 & 1.0 & 4.0 & 15.0 & $174,389.0$ & 253,789 \\
\hline
\end{tabular}

Panel C: Conditional on having an email address in the data set

\begin{tabular}{|c|c|c|c|c|c|c|c|}
\hline & Mean & Min & 25th & 50th & 75th & Max & $\mathbf{n}$ \\
\hline Total assets & $1,194.9$ & 0.0 & 4.8 & 101.4 & 752.8 & $11,100,000.0$ & $1,664,295$ \\
\hline Turnover & $1,607.6$ & 0.0 & 19.1 & 173.5 & $1,293.7$ & 2,908,000.0 & $1,054,339$ \\
\hline Employees & 26.3 & 0.0 & 1.0 & 4.0 & 15.0 & $174,389.0$ & 762,992 \\
\hline
\end{tabular}

Panel D: Survey respondent categorical size: Total assets

\begin{tabular}{|c|c|c|c|}
\hline Category & Frequency & Percent & Description \\
\hline 1 & 807 & $55 \%$ & Less than 1 million \\
\hline 2 & 337 & $23 \%$ & Between 1 million and 5 million \\
\hline 3 & 100 & $7 \%$ & Between 5 million and 10 million \\
\hline 4 & 63 & $4 \%$ & Between 10 million and 20 million \\
\hline 5 & 95 & $7 \%$ & Greater than 20 million \\
\hline 6 & 54 & $4 \%$ & I do not know \\
\hline
\end{tabular}

Panel E: Survey respondent categorical size: Turnover

\begin{tabular}{|c|c|c|c|}
\hline Category & Frequency & Percent & Des \\
\hline 1 & 708 & $49 \%$ & Less than 1 million \\
\hline 2 & 388 & $27 \%$ & Between 1 million and 5 million \\
\hline 3 & 108 & $7 \%$ & Between 5 million and 10 million \\
\hline 4 & 63 & $4 \%$ & Between 10 million and 20 million \\
\hline 5 & 130 & $9 \%$ & Greater than 20 million \\
\hline 6 & 45 & $3 \%$ & I do not know \\
\hline
\end{tabular}

Panel F: Survey respondent categorical size: Employees

\begin{tabular}{|c|c|c|c|}
\hline Category & Frequency & Percent & Description \\
\hline 1 & 930 & $64 \%$ & Less than 10 \\
\hline 2 & 376 & $26 \%$ & Between 11 and 50 \\
\hline 3 & 66 & $5 \%$ & Between 51 and 100 \\
\hline 4 & 30 & $2 \%$ & Between 101 and 200 \\
\hline 5 & 33 & $2 \%$ & Greater than 201 \\
\hline 6 & 19 & $1 \%$ & I do not know \\
\hline
\end{tabular}




\section{TABLE3}

Which of the following best describes the reas on why your company publicly files its financial statements $(\mathrm{N}=\mathbf{1 6 5 9})$

Public filing is required by law, and my company would not voluntarily do so if the law/ government did not require it.

$62.0 \%$

Public filing is required by law, but my company would voluntarily file public financial statements anyway.

Public filing is not required by law, but the company decides to publicly file financial statements anyway.

\section{TABLE 4}

\begin{tabular}{lcc}
$\begin{array}{l}\text { How much net benefit do you believe your company derives from } \\
\text { having its financial statements publicly available? }(\mathbf{N = 1 5 8 4 ;} \mathbf{2 5})\end{array}$ & $\begin{array}{c}\text { Private Firm } \\
\text { Opinions }\end{array}$ & $\begin{array}{c}\text { Standard Setter } \\
\text { Opinions }\end{array}$ \\
\hline \hline The costs are larger than the benefits & $36.5 \%$ & $16.0 \%$ \\
$\ldots$ & $14.8 \%$ & $20.0 \%$ \\
The costs and benefits are approximately equal. & $32.8 \%$ & $12.0 \%$ \\
$\ldots$ & $7.7 \%$ & $24.0 \%$ \\
The benefits are larger than the costs. & $8.2 \%$ & $28.0 \%$ \\
\hline \hline
\end{tabular}


TABLE 5

\begin{tabular}{|c|c|c|c|c|}
\hline \multirow[t]{2}{*}{$\begin{array}{l}\text { Among the set of individuals below, please indicate the extent to which } \\
\text { you believe each individual will download and view your publicly } \\
\text { available financial statements. }\end{array}$} & \multicolumn{2}{|c|}{ Private Firm Opinions } & \multicolumn{2}{|c|}{$\begin{array}{l}\text { Standard Setter } \\
\text { Opinions }\end{array}$} \\
\hline & $\begin{array}{l}\text { Definitely } \\
\text { Will }\end{array}$ & $\begin{array}{c}\text { Definitely } \\
\text { Will Not }\end{array}$ & $\begin{array}{c}\text { Definitely } \\
\text { Will }\end{array}$ & $\begin{array}{r}\text { Definitely } \\
\text { Will Not }\end{array}$ \\
\hline Lenders and creditors $(N=1411 ; 25)$ & $69.4 \%$ & $16.2 \%$ & $84.0 \%$ & $8.0 \%$ \\
\hline Competitors $(N=1426 ; 25)$ & $61.4 \%$ & $14.2 \%$ & $92.0 \%$ & $4.0 \%$ \\
\hline Tax authorities $(N=1427 ; 25)^{*}$ & $58.4 \%$ & $22.3 \%$ & $84.0 \%$ & $8.0 \%$ \\
\hline Suppliers $(N=1417 ; 25)$ & $46.4 \%$ & $25.8 \%$ & $72.0 \%$ & $4.0 \%$ \\
\hline Regulators/Government $(N=1391 ; 25) *$ & $43.6 \%$ & $30.1 \%$ & $84.0 \%$ & $8.0 \%$ \\
\hline Potential shareholders $(N=1348 ; 25)$ & $42.6 \%$ & $41.3 \%$ & $84.0 \%$ & $4.0 \%$ \\
\hline Existing shareholders ( $N=1380 ; 25)$ & $33.0 \%$ & $54.4 \%$ & $52.0 \%$ & $20.0 \%$ \\
\hline Current management team $(N=1371 ; 25)$ & $32.6 \%$ & $52.7 \%$ & $36.0 \%$ & $24.0 \%$ \\
\hline Customers $(N=1427 ; 25)$ & $28.8 \%$ & $41.3 \%$ & $44.0 \%$ & $16.0 \%$ \\
\hline General interest parties (e.g., neighbors, relatives, etc.) $(N=1402 ; 25)$ & $13.1 \%$ & $62.8 \%$ & $32.0 \%$ & $44.0 \%$ \\
\hline Employees $(N=1390 ; 24)$ & $12.2 \%$ & $68.0 \%$ & $41.7 \%$ & $16.7 \%$ \\
\hline Others $(N=1148)$ & $7.1 \%$ & $59.4 \%$ & --- & --- \\
\hline
\end{tabular}

*These categories were grouped in the survey provided to standard setters.

TABLE 6

Have you or someone else in your company ever downloaded financial statements of another company?

Competitors $(N=2032)$

\begin{tabular}{cc} 
Yes & No \\
\hline $47.8 \%$ & $52.2 \%$
\end{tabular}

Customers $(N=2032)$

45.7\% $\quad 54.3 \%$

Suppliers $(N=2032)$

$36.7 \% \quad 63.3 \%$

Neighbor's company $(N=2032)$

$10.1 \% \quad 89.9 \%$

Others $(N=2032)$

$7.1 \% \quad 92.9 \%$


TABLE 7

\begin{tabular}{|c|c|c|c|c|}
\hline \multirow[t]{2}{*}{$\begin{array}{l}\text { Regardless of whether your company publicly files its financial } \\
\text { statements, please rate your concerns in doing so. }\end{array}$} & \multicolumn{2}{|c|}{$\begin{array}{l}\text { Private Firm } \\
\text { Opinions }\end{array}$} & \multicolumn{2}{|c|}{$\begin{array}{l}\text { Standard Setter } \\
\text { Opinions }\end{array}$} \\
\hline & $\begin{array}{c}\text { Important } \\
\text { concern }\end{array}$ & $\begin{array}{c}\text { Not a } \\
\text { concern }\end{array}$ & $\begin{array}{c}\text { Important } \\
\text { concern }\end{array}$ & $\begin{array}{c}\text { Not a } \\
\text { concern }\end{array}$ \\
\hline $\begin{array}{l}\text { Competitors are able to see the company's leverage (or amount of } \\
\text { debt) (N=1557; Not asked) }\end{array}$ & $42.2 \%$ & $39.2 \%$ & --- & --- \\
\hline Competitors are able to see the company's performance $(N=1569 ; 25)$ & $39.2 \%$ & $40.4 \%$ & $44.0 \%$ & $28.0 \%$ \\
\hline $\begin{array}{l}\text { Do not want my customers or suppliers to observe my company's } \\
\text { financial performance }(N=1557 ; \text { Not asked })\end{array}$ & $32.7 \%$ & $45.2 \%$ & --- & --- \\
\hline $\begin{array}{l}\text { Do not want neighbors, friends, or family to observe my company's } \\
\text { financial performance }(N=1554 ; 25)\end{array}$ & $31.3 \%$ & $49.2 \%$ & $16.0 \%$ & $64.0 \%$ \\
\hline It is time consuming to comply with such a law $(N=1535 ; 25)$ & $29.8 \%$ & $42.7 \%$ & $40.0 \%$ & $36.0 \%$ \\
\hline Others $(N=412 ;$ Not asked $)$ & $17.5 \%$ & $52.4 \%$ & --- & --- \\
\hline
\end{tabular}

TABLE 8

Which of the following best describes the reas on why your company has its financial statements audited $(\mathrm{N}=778)$

An audit is required by law, and the company would not voluntarily purchase an audit if it was not required.

$32.0 \%$

An audit is required by law, but the company would voluntarily purchase an audit anyway.

An audit is not required by law, but the company decided to purchase an audit anyway. 
TABLE 9

\begin{tabular}{lcc}
\hline $\begin{array}{l}\text { How much net benefit do you believe your company derives from } \\
\text { having its financial statements audited? (N=762; 25) }\end{array}$ & $\begin{array}{c}\text { Private Firm } \\
\text { Opinions }\end{array}$ & $\begin{array}{c}\text { Standard } \\
\text { Setter } \\
\text { Opinions }\end{array}$ \\
\hline \hline The costs are larger than the benefits & $21.8 \%$ & $4.2 \%$ \\
$\ldots$ & $11.6 \%$ & $4.2 \%$ \\
The costs and benefits are approximately equal. & $38.3 \%$ & $20.8 \%$ \\
$\ldots$ & $15.1 \%$ & $50.0 \%$ \\
The benefits are larger than the costs. & $13.3 \%$ & $25.0 \%$ \\
\hline \hline
\end{tabular}

TABLE 10

Please indicate the extent to which you agree or disagree with the following statements

\begin{tabular}{lcc}
\hline \hline & Important concern & Not a concern \\
The auditor's charge is more than I am willing to pay. $(N=597)$ & $60.3 \%$ & $20.6 \%$ \\
An audit requires too much of management's time. $(N=591)$ & $54.0 \%$ & $23.0 \%$ \\
$\begin{array}{l}\text { I do not see any benefit in having the financial statements audited } \\
(N=606)\end{array}$ & $42.1 \%$ & $33.3 \%$ \\
Others $(N=135)$ & $45.2 \%$ & $25.9 \%$ \\
\hline \hline
\end{tabular}


TABLE 11

\begin{tabular}{lcccc}
\hline $\begin{array}{l}\text { Among the set of individuals below, please indicate the extent to } \\
\text { which you think benefit from your company's financial statement } \\
\text { audit. }\end{array}$ & \multicolumn{2}{c}{$\begin{array}{c}\text { Private Firm } \\
\text { Opinions }\end{array}$} & \multicolumn{2}{c}{$\begin{array}{c}\text { Standard Setter } \\
\text { Opinions }\end{array}$} \\
\hline \hline & $\begin{array}{r}\text { Definitely } \\
\text { Will }\end{array}$ & $\begin{array}{c}\text { Definitely } \\
\text { Will Not }\end{array}$ & $\begin{array}{c}\text { Definitely } \\
\text { Will }\end{array}$ & $\begin{array}{r}\text { Definitely } \\
\text { Will Not }\end{array}$ \\
\cline { 2 - 6 } & $61.9 \%$ & $20.2 \%$ & $96.0 \%$ & $4.0 \%$ \\
Tax authorities $(N=685 ; 25) *$ & $59.6 \%$ & $20.7 \%$ & $100.0 \%$ & $0.0 \%$ \\
Lenders and creditors $(N=676 ; 25)$ & $58.6 \%$ & $26.3 \%$ & $80.0 \%$ & $8.0 \%$ \\
Existing shareholders $(N=677 ; 25)$ & $49.9 \%$ & $30.5 \%$ & $76.0 \%$ & $8.0 \%$ \\
Potential shareholders $(N=663 ; 25)$ & $49.3 \%$ & $28.6 \%$ & $28.0 \%$ & $28.0 \%$ \\
Current management team $(N=681 ; 25)$ & $48.8 \%$ & $26.2 \%$ & $96.0 \%$ & $4.0 \%$ \\
Regulators/Government $(N=672 ; 25) *$ & $35.8 \%$ & $35.1 \%$ & $64.0 \%$ & $8.0 \%$ \\
Suppliers ( $N=678 ; 25)$ & $28.9 \%$ & $44.7 \%$ & $40.0 \%$ & $24.0 \%$ \\
Competitors $(N=664 ; 25)$ & $26.7 \%$ & $46.6 \%$ & $28.0 \%$ & $20.0 \%$ \\
Customers $(N=674 ; 25)$ & $18.7 \%$ & $60.5 \%$ & $44.0 \%$ & $16.0 \%$ \\
Employees $(N=664 ; 25)$ & $8.8 \%$ & $66.9 \%$ & $16.0 \%$ & $48.0 \%$ \\
Others / General interest $(N=160 ; 25)$
\end{tabular}

*These categories were grouped in the survey provided to standard setters.

TABLE 12

Opinions about private company financial reporting regulation

Private Firm Standard Setter Opinions Opinions

$\%$ Yes

$\%$ Yes

In the U.S., private limited companies are not required by law to have their financial statements audited by a public accountant. Do you think your country should adopt a similar approach? That is, should financial statement $54.5 \%$

$26.1 \%$ audits be completely voluntary? $(N=1477 ; 23)$

In the U.S., private limited companies are not required by law to make their financial statements available to the public or file them with a government regulator. Do you think your country should adopt a similar approach? 